Article

\title{
On the Use of Sodium Chloride and Calcined Diatomite Sludge as Additives to Improve the Engineering Properties of Bricks Made with a Clay Earth from Jun (Granada, Spain)
}

\author{
María Laura Elias ${ }^{1}$ and Giuseppe Cultrone ${ }^{2, *(D)}$ \\ 1 Laboratorio de Técnicas y Materiales, Facultad de Arquitectura, Diseño y Urbanismo, \\ Universidad Nacional del Litoral, Santa Fe S3000, Argentina; mlelias@unl.edu.ar \\ 2 Departamento de Mineralogía y Petrología, Facultad de Ciencias, Universidad de Granada, \\ Granada 18002, Spain \\ * Correspondence: cultrone@ugr.es; Tel.: +34-958240077
}

Received: 5 December 2018; Accepted: 17 January 2019; Published: 21 January 2019 updates

\begin{abstract}
Solid bricks manufactured out of clayey earth from a quarry near the city of Granada (Spain) were studied and compared with others to which two additives were added during the kneading of the raw material: Calcined diatomite sludge and sodium chloride. Samples with and without additives were fired at $800{ }^{\circ} \mathrm{C}, 950{ }^{\circ} \mathrm{C}$, and $1100{ }^{\circ} \mathrm{C}$. New mineral phases were formed in the bricks after firing. These included gehlenite, diopside, and plagioclase, which is gradually enriched in calcium, and microcline, which is transformed into sanidine. Mullite and molysite also appeared in the bricks made with added salt. Porosity increased substantially in the bricks that contained diatomite sludge, while the addition of sodium chloride accelerated the mineralogical transformations and caused sintering at relatively low temperatures of $800{ }^{\circ} \mathrm{C}$. The bricks became more compact and less anisotropic as the firing temperature increased. This behaviour was less evident in the bricks with added diatomite sludge, which alters the orientation of the phyllosilicates. The bricks fired at $1100{ }^{\circ} \mathrm{C}$ had the best physical parameters. However, the bricks with added sodium chloride fired at $800{ }^{\circ} \mathrm{C}$ reached hygric and compactness values that were at least similar to bricks from the other groups fired at $950{ }^{\circ} \mathrm{C}$.
\end{abstract}

Keywords: solid bricks; calcined diatomite sludge; sodium chloride; mineralogy; physical changes

\section{Introduction}

Bricks are some of the oldest manmade masonry building materials, which is why they are often found in monuments with great heritage value [1]. For bricks to last, they must have certain physical and mineralogical properties [2-6]. These properties are undoubtedly related to the composition of the raw material and the manufacturing process, such that the chemical and mineralogical composition, the grain size, firing temperature, and the atmosphere (oxidation or reduction) inside the kiln all have a considerable influence on the porosity, mechanical resistance, and colour of the bricks [7-11]. Bricks are usually made out of local earths, which means that the composition varies from one region to the next. This also makes them very economical and easy to produce. The brick production process has changed little over thousands of years. Perhaps the most important change is that today there is tight control over the different stages of the production process to ensure that a more standardized, high quality material is obtained. In spite of these controls, worn or damaged bricks can sometimes be found in new buildings. This may be due to defects in the production process [12]. For this reason, the brick industry is experimenting with new resources and ideas aimed at improving the properties 
of the fired product [13]. A significant number of research papers have been written on different clayey raw materials and their performance in firing tests, with a view to their possible use in the brick industry [14-17]. Recently, however, researchers have been focusing on the possibility of using waste products from different industrial activities in the manufacture of building materials, as this would help deal with the huge amounts of waste produced in this way and the problems associated with their disposal [18-21]. Waste products of this kind could be used, for example, as additives in the mix used in the manufacture of bricks. These additives can either perform functions that complement those of the clayey earth or they can provide new properties for the ceramic paste. Additives are used to correct the proportions of the tempers, melting agents, and colorants in the original clayey earth and also to reduce the density of the samples, alter the porous system, and reduce the thermal conductivity [22]. There is a very varied bibliography about the use of additives in bricks, as well as various reviews of the literature that present the results in a comparative form [23-27]. Unfortunately, almost all these cases are specific, often isolated studies, the results of which seem promising, but have not been transferred to large-scale production.

The objective of this paper is to assess the potential of diatomite sludge and common salt as additives in brick production, as little research has so far been done on this issue. There are clear differences between these two additives in terms of composition, origin, and organic matter content, differences that will be reflected in the mineralogy and texture of the fired materials. Diatomite is a sedimentary rock that is formed by the accumulation of skeletons of diatoms, unicellular marine algae composed of amorphous silica (generally opal). Diatomite is commonly used in the filtration process in the manufacture of beer, wine, and other liquids after its calcination at between 900 and $1000{ }^{\circ} \mathrm{C}$. At this temperature, the organic matter in these micro-organisms is burnt and the surface area of the sediment increases, freeing up space in the porous system. Sodium carbonate is added as a melting agent [28]. After calcination, the most important mineralogical change in the material is the transformation of opal into cristobalite and quartz $[29,30]$. During the filtering of the beer, the diatomite traps the yeast used in the fermentation process plus other particles remaining in the liquid. There are currently no obvious reuses for this waste product, which means that its application in brickmaking could be beneficial for both the brick industry and the environment. So far, little research has been done into the possible reuse of calcined diatomite sludge in the construction industry and, more specifically, in the manufacture of bricks. The very limited bibliography on additives in the brick production process analyses the use of natural diatomite [31] or of diatomite mixed with fly ash [32]. These additives cause changes in the porosity and mechanical properties of the fired materials. Galán Arboledas et al. [33] observed that higher amounts of calcined diatomite waste led to an increase in the porosity of extruded bricks and a reduction in their thermal conductivity. However, they did not provide any information about the mineralogical evolution of the bricks made with the addition of diatomite.

Halite has a whole variety of applications, ranging from its use in the food sector as a condiment or preservative to its use in the industry in the production of hydrochloric acid and sodium carbonate, among other products. This mineral is easily available in nature. However, as with diatomite sludge, little research has been done on the use of salt as an additive in brick production. Ancient civilizations perceived some improvements in ceramic production after the clayey earths were kneaded with seawater [34,35]. From a textural point of view, research has demonstrated that salt acts as a melting agent at low firing temperatures [36]. Other authors also observed that the addition of $0.5-1 \%$ common salt can inhibit lime-blowing, a problem that arises when carbonates are present in the raw materials, which can cause the bricks to break or burst [37]. The same authors observed the development of yellow stains on the surface of the bricks when salt was used, but offered no explanations as to why these stains appeared.

There is only very limited data available on the interaction of these additives with bricks and their potential use in the brick industry, a gap which this research tries to fill. The comparison of results between bricks made with and without these additives will provide new data about the mineralogical evolution of fired products, as well as the differences that they give rise to in the porous system, 
compactness, and colour. This will allow us to identify the best (or worst) characteristics of the fired pieces, thus optimizing their physical properties and reducing production costs due to the need for smaller amounts of raw material (in the case of calcined diatomite sludge) or lower firing temperatures (in the case of sodium chloride).

\section{Materials and Methods}

\subsection{Raw Materials, Additives, Preparation, and Firing of the Test Samples}

The clayey earth selected for making the bricks comes from the village of Jun, near Granada (Spain). Geologically speaking, these are grey clays, silts, and sands from the mid-late Turolian Age. The clays are interspersed with small layers of gypsum, which are increasingly frequent towards the top of the formation, and occasionally reddish carbonates that are rich in gastropods.

As regards the additives, the diatomite sludge with organic remains (above all barley and corn) was supplied by the Spanish beer manufacturer, Cervezas Alhambra S.L. (Granada, Spain), which uses diatomite in the beer filtering process. To reap the maximum environmental benefits, as much sludge as possible should be added to the mix, providing of course that this does not have a detrimental effect on the physical quality of the bricks [19]. In previous research [33], a proportion of $10 \mathrm{wt} . \%$ diatomite sludge mixed with clayey earth was found to be the maximum amount that could be added to produce bricks acceptable to the construction sector. The sodium chloride is edible sea salt produced by the company, Salinera Española S.A. (Palma de Mallorca, Spain), which is obtained by natural evaporation of seawater. $30 \mathrm{wt} \%$ salt was added to the water used for kneading the clay to analyse possible improvements in the quality of the fired pieces, such as, for example, greater vitrification. The salt was dissolved in running water before being used to knead the clayey earth. The salt concentration used in this work is higher than that used by other authors [37] or than in seawater. The advantage of a higher concentration is that it enhances the changes to be identified at mineralogical and physical levels.

The bricks were made according to craft techniques. The first stage was to remove the largest fragments (centimetre size) composed above all of gypsum and carbonates. Then, approximately $1 \mathrm{~kg}$ of clayey earth was mixed with $500 \mathrm{~mL}$ of water. This amount was calculated by adding the water little by little until the paste acquired the necessary consistency for moulding the pieces. The paste was then put in a wooden mould measuring $15 \times 20 \times 4 \mathrm{~cm}^{3}$ and was compacted by pressing down initially with the palm of the hand and later with a rolling-pin. The pastes with and without additives were taken out of their moulds while still damp and cut with tensor wire to obtain cubic samples with $4 \mathrm{~cm}$ sides and elongated, prism-shaped samples measuring $2 \times 4 \times 8 \mathrm{~cm}^{3}$. They were then left outside to dry for approximately one week until they had lost all the kneading water.

The dried raw bricks were then fired in a Herotec CR-35 electric kiln in an oxidation atmosphere at 800,950 , and $1100{ }^{\circ} \mathrm{C} .950{ }^{\circ} \mathrm{C}$ is one of the most commonly used temperatures in brick production. The other two firing temperatures, one lower than $950{ }^{\circ} \mathrm{C}$ and the other higher, were chosen to study the changes that take place in the mineralogy and the physical properties of the bricks over a range of $300{ }^{\circ} \mathrm{C}$. The temperature was kept constant at $100^{\circ} \mathrm{C}$ for $1 \mathrm{~h}$ to ensure that there was no moisture left in any of the raw, unfired pieces. The samples were then heated up to the selected firing temperature at a heating speed of $2{ }^{\circ} \mathrm{C} / \mathrm{min}$. Once this temperature had been reached, it was maintained for $3 \mathrm{~h}$. Finally, the bricks were left to cool inside the kiln until the next day, with the whole firing-cooling process lasting about $24 \mathrm{~h}$. When the bricks were taken out of the kiln, they were submerged in water in order to eliminate possible grains of calcium oxides that could cause them to shatter due to lime blowing [37].

Overall, nine types of bricks were prepared. These were labelled as J, JS, and JD in order to distinguish samples with no additives (J) from those made with added salt (JS) and those made with calcined diatomite sludge (JD). Each label is followed by a number $(800,950$, or 1100) specifying the firing temperature in ${ }^{\circ} \mathrm{C}$. 


\subsection{Analytical Techniques}

\subsubsection{Chemical and Mineralogical Characterization}

The clayey material and the calcined diatomite sludge were studied using X-ray fluorescence (XRF). A Philips Magix Pro PW-2440 wavelength dispersive sequential spectrometer with a $4 \mathrm{kV}$ X-ray generator was used to analyse major and trace elements. Prior to the analysis, $5 \mathrm{~g}$ per sample was finely milled in an agate mortar. The accuracy of the analytical results was evaluated by comparison with certified values of analysed reference materials [38]. Typical accuracy is higher than $1.5 \%$ relative to a concentration of $10 \%$. Loss on ignition was determined gravimetrically as the weight loss was recorded between 110 and $1000{ }^{\circ} \mathrm{C}$. The De Jongh model [39] was followed to convert the XRF intensities into concentrations.

The identification of the mineral phases in the raw material, the calcined diatomite sludge, and the bricks with and without additives fired between 800 and $1100{ }^{\circ} \mathrm{C}$ was carried out by X-ray diffraction (XRD) using the disoriented powder method. Samples were milled in an agate mortar to a particle size of less than $0.053 \mathrm{~mm}$. A Philips X'Pert PRO diffractometer was used with the following working conditions: CuK $\alpha$ radiation $(\lambda=1.5405 \AA), 45 \mathrm{kV}$ voltage, $40 \mathrm{~mA}$ current, $3-60^{\circ} 2 \theta$ explored area, and $0.12 \theta \mathrm{s}^{-1}$ goniometer speed. The interpretation of results was performed using the XPowderX computer program [40]. Quantitative analysis of the mineral phases was performed using the non-linear least square method to fit full-profile diffractograms and the results were compared with standard values in the database. For this task, the program implements the following refinements and corrections: a) Theoretical mass absorption coefficient of the samples as a function of the chemistry and density of each phase found in the database sheets; b) pattern intensity ratio (PIR) correction, initially using the experimental RIR (reference intensity ratio) for each mineral phase contained in the sample and finally obtaining a PIR value upon full pattern refinement. The American Mineralogist Crystal Structure Database (AMCSD) was used to identify the mineral phases. An indicative value of the amorphous versus crystalline phases $(\mathrm{a} / \mathrm{c})$ ratio was provided. This ratio is based on the mean value of the intensities, standard deviation, and area of the crystal reflection [40]. In order to obtain the mineralogical composition of the grain fraction measuring less than $2 \mu \mathrm{m}, 100 \mathrm{~g}$ of the raw material was submerged in a beaker with deionized water treated with acetic acid $\left(\mathrm{CH}_{3} \mathrm{COOH}\right)$ with $1 \mathrm{~N}$ concentration to eliminate carbonates. This treatment was repeated until the reaction ceased. The sample was then washed several times to eliminate the acid in the water, and hydrogen peroxide $\left(\mathrm{H}_{2} \mathrm{O}_{2}\right)$ with a concentration of 20 vol. \% was added to eliminate any possible organic matter. After that, sodium hexametaphosphate was added $(5 \mathrm{~g} / \mathrm{L})$ to separate any aggregates that might have formed. The fraction below $2 \mu \mathrm{m}$ was separated using a Kubota Ks-8000 centrifuge and the oriented aggregate method was used to study it with X-ray diffraction. Air-dried oriented aggregate (OA) was prepared for general study. Other aggregates were also prepared: Dissolved with ethylene-glycol (OA + EG) to detect the presence of smectites and chlorites [41], aggregates dissolved with dimethyl-sulfoxide (OA + DMSO) to confirm the presence of kaolinite [42], and aggregates heated at $550{ }^{\circ} \mathrm{C}$ to destroy kaolinite and confirm the presence of chlorite.

\subsubsection{Physical Characterization}

Mercury intrusion porosimetry (MIP) was used to study the porous system of the bricks using a Micromeritics Autopore III 9410 apparatus (Norcross, GA, USA). This porosimeter can exert a maximum pressure of $414 \mathrm{MPa}$ and can identify pores with radii comprised between 0.003 and $360 \mu \mathrm{m}$. Freshly cut chips of about $1 \mathrm{~cm}^{3}$ were oven dried for $24 \mathrm{~h}$ at $100{ }^{\circ} \mathrm{C}$ and then analysed. Pore size measurements were taken on two fragments of each brick type. The specific surface area (SSA), open porosity to $\mathrm{Hg}\left(\mathrm{P}_{\mathrm{OMIP}}\right)$, and apparent and real density values $\left(\rho_{\mathrm{amIP}}\right.$ and $\left.\rho_{\mathrm{rMIP}}\right)$ were also calculated.

One of the most important aspects to consider when evaluating the durability of construction materials is their hygric behaviour, i.e., how these materials absorb and evaporate fluids over time. 
This is because decay processes are often affected by the flow of water inside the porous system [43]. Water absorption at atmospheric pressure $\left(A_{b}\right)$ [44] and water absorption under vacuum $\left(A_{f}\right)$ [45] were measured as follows:

$$
\begin{aligned}
& A_{b}=\frac{M_{l}-M_{0}}{M_{0}} \times 100 ; \\
& A_{f}=\frac{M_{S}-M_{0}}{M_{0}} \times 100,
\end{aligned}
$$

where $M_{0}$ is the mass of the dried sample, $M_{1}$ is the mass of the sample saturated with water at atmospheric pressure, and $M_{S}$ is the mass of the sample saturated with water under vacuum. The drying index (Di) was determined as follows [46]:

$$
D i=\frac{\int_{t_{0}}^{t_{f}} f\left(M_{t}\right) d t}{M_{S} \times t_{f}},
$$

where $M_{t}$ represents the decreasing water weight content as a function of time and $t_{0}$ and $t_{f}$ are, respectively, the start and end times for the test. A capillary test [47] was carried out to determine the capillarity coefficient $\left(C_{\mathcal{c}}\right)$ and the capillarity height $\left(H_{\mathcal{c}}\right)$ [45] as follows:

$$
\begin{gathered}
C_{c}=\frac{M_{t}-M_{0}}{A \sqrt{t}} ; \\
H_{c}=\frac{h}{\sqrt{t}}
\end{gathered}
$$

where $M_{t}$ is the amount of water absorbed at time $t, A$ is the surface of the sample in contact with the water, and $h$ is the height of the water rise by capillarity at time $t$.

These tests enabled us to ascertain the degree of pore interconnection $\left(A_{x}\right)$ [48], the saturation coefficient $(S)$, apparent $\left(\rho_{\mathrm{a}}\right)$ and real densities $\left(\rho_{\mathrm{r}}\right)$, and open porosity $\left(P_{o}\right)$ [49]. These parameters were calculated as follows:

$$
\begin{aligned}
& A_{x}=\frac{A_{f}-A_{b}}{A_{f}} \times 100 \\
& S=\frac{M_{48 h}-M_{0}}{M_{S}-M_{0}} \times 100 \\
& \rho_{\mathrm{a}}=\frac{M_{0}}{M_{S}-M_{H}} \times 100 \\
& \rho_{\mathrm{r}}=\frac{M_{0}}{M_{0}-M_{H}} \times 100 \\
& P_{o}=\frac{M_{S}-M_{0}}{M_{S}-M_{H}} \times 100
\end{aligned}
$$

where $\mathrm{M}_{48 \mathrm{~h}}$ is the mass of the sample after $48 \mathrm{~h}$ immersion in water at atmospheric pressure and $M_{H}$ is the mass of the sample saturated with water under vacuum and weighed in water.

Cubic samples were used for absorption-drying tests and prism-shaped samples for the capillarity test. Even though the UNE-EN 1925 norm [47] requires the use of cubic samples in the capillary test, elongated samples (twice as long) were used to better measure the capillarity height, given the rapid ascent of water in these materials. Hygric tests were performed under controlled thermo-hygrometric conditions $\left(T=18^{\circ} \mathrm{C}\right.$ and $\left.R H=35 \%\right)$ using deionized water. Three samples from each brick group were analysed.

Of the various available techniques for determining the physical properties of bricks, ultrasounds and spectrophotometry are particularly attractive because they are not destructive. The compactness of the bricks was measured using a Control 58-E4800 ultrasonic pulse velocity tester with a resolution of $0.1 \mu \mathrm{m}, 54 \mathrm{kHz}$ transducers, and a contact surface of $3 \mathrm{~cm}$ in diameter under controlled temperature and hygrometric conditions $\left(20^{\circ} \mathrm{C}\right.$ and relative humidity of $35 \%$ ). An ultrasound eco-gel (Transonic Gel, Telic S.A., Barcelona, Spain) was used to obtain a good coupling between the transducers and the brick surfaces. The propagation velocity of the $\mathrm{P}$ waves was measured using the transmission method 
in accordance with the ASTM D2845 standard [50] on dry cubic samples in three orthogonal directions: $V_{P 1}$ is the velocity perpendicular to the compaction plane of the raw material in the wooden box and $V_{P 2}$ and $V_{P 3}$ are the velocities parallel to it. The structural $(\Delta M)$ and relative anisotropies $(\Delta m)$ were calculated as follows [51]:

$$
\begin{gathered}
\Delta M=\left(1-\frac{2 V_{P 1}}{V_{P 2}+V_{P 3}}\right) \times 100 ; \\
\Delta m=\frac{2\left(V_{P 2}-V_{P 3}\right)}{V_{P 2}+V_{P 3}} \times 100,
\end{gathered}
$$

Three samples per brick type were tested.

The colour of the bricks was determined by spectrophotometry in accordance with the UNE-EN 15886 standard [52] in order to quantify any changes produced by additives or firing temperatures. A Konica-Minolta CM-700d spectrophotometer (Tokyo, Japan) was used for this purpose. The working conditions were: A circular measurement area of $8 \mathrm{~mm}$ diameter, D65 illuminant, $10^{\circ}$ vision angle, SCI/SCE mode, and light radiation range between 400 and $700 \mathrm{~nm}$. The CIELab system was used to calculate the lightness $\left(L^{*}\right.$, which varies from 0 to 100$)$ and chromatic ( $a^{*}$ and $b^{*}$, which vary from -60 to +60 ) parameters. The spectrophotometer performs an auto averaging of two values on the measurement area. Six measurements were made for each brick type. In order to verify the possible effects of the additives on the colour, the colours of the samples made with and without additives were compared by measuring the colour difference. The colour difference, $\Delta E$, was calculated as follows:

$$
\Delta E=\sqrt{\left(L_{1}^{*}-L_{2}^{*}\right)^{2}+\left(a_{1}^{*}-a_{2}^{*}\right)^{2}+\left(b_{1}^{*}-b_{2}^{*}\right)^{2}}
$$

where $L_{1}^{*}, a_{1}^{*}$, and $b_{1}^{*}$ are the lightness and chromaticity values for the bricks without additives and $L_{2}^{*}$, $a_{2}^{*}$, and $b_{2}^{*}$ are those for bricks with additives.

\section{Results}

\subsection{Raw Materials and Additives}

The clayey earth from Jun is composed above all of silica and alumina and appreciable amounts of calcium and iron. The diatomite sludge is mainly composed of silica and small amounts of alumina, calcium, iron, and sodium. The loss on ignition (LOI) is $10 \%$ in the clayey earth and $15 \%$ in the diatomite sludge. The LOI values may be due to the likely presence of carbonates in the clayey earth and of organic matter in the sludge (Table 1).

Table 1. Chemical analysis of major oxides (in wt\%) and trace elements (in ppm) in the clayey earth raw material from Jun and the calcined diatomite sludge. LOI = loss on ignition.

\begin{tabular}{cccccccccccc}
\hline Sample & $\mathbf{S i O}_{2}$ & $\mathrm{Al}_{2} \mathbf{O}_{3}$ & $\mathbf{F e}_{2} \mathbf{O}_{3}$ & $\mathbf{M n O}$ & $\mathbf{M g O}$ & $\mathbf{C a O}$ & $\mathbf{N a}_{2} \mathbf{O}$ & $\mathbf{K}_{\mathbf{2}} \mathbf{O}$ & $\mathbf{T i O}_{2}$ & $\mathbf{P}_{2} \mathbf{O}_{5}$ & $\mathbf{L O I}$ \\
\hline Raw & 49.27 & 16.92 & 5.69 & 0.07 & 2.50 & 9.65 & 0.99 & 2.98 & 0.67 & 0.14 & 10.39 \\
Diatomite & 66.77 & 5.45 & 2.75 & 0.04 & 1.59 & 3.00 & 2.27 & 1.12 & 0.34 & 0.48 & 15.71 \\
\hline & $\mathbf{Z r}$ & $\mathbf{V}$ & $\mathbf{C r}$ & $\mathbf{C o}$ & $\mathbf{N i}$ & $\mathbf{C u}$ & $\mathbf{Z n}$ & $\mathbf{G a}$ & $\mathbf{B a}$ & $\mathbf{A s}$ & $\mathbf{M o}$ \\
\hline Raw & 201.10 & 168.10 & 97.80 & 21.80 & 44.90 & 24.80 & 85.30 & 18.30 & 423.60 & 24.30 & 4.30 \\
Diatomite & 79.90 & 194.90 & 136.60 & 3.20 & 62.70 & 216.50 & 273.30 & 4.30 & 448.90 & 7.40 & 8.70 \\
\hline & $\mathbf{N b}$ & $\mathbf{P b}$ & $\mathbf{R b}$ & $\mathbf{S b}$ & $\mathbf{S r}$ & $\mathbf{T h}$ & $\mathbf{U}$ & $\mathbf{Y}$ & & & \\
\hline Raw & 18.20 & 18.50 & 105.10 & 0.60 & 782.60 & 7.30 & 0.30 & 19.80 & & & \\
Diatomite & 5.80 & 22.30 & 32.90 & 1.50 & 75.60 & 7.30 & 6.60 & 14.60 & & & \\
\hline
\end{tabular}

In mineralogical terms, the clayey earth is composed above all of quartz and phyllosilicates and smaller quantities of calcite, dolomite, plagioclases, and K-feldspars (Figure 1a and Table 2). Gypsum was also identified. This sulphate is quite common in this soil and was formed in the Granada depression during the Turolian Age due to processes of chemical precipitation and evaporation of water from lacustrine environments [53]. The clay fraction is composed of illite, kaolinite, chlorite, 
smectites, and paragonite (Figure 1b). After treatment with ethylene glycol, the displacement of the reflection (001) of the smectites shifted from $14 \AA$ to $17 \AA$, approximately, was observed. This indicates that smectites can expand, leaving the reflection (001) of the chlorite (previously masked by the smectites) more visible. The presence of kaolinite was confirmed using dimethyl sulfoxide, by the displacement of the reflection (001) to $11.2 \AA$. Finally, heating to $550{ }^{\circ} \mathrm{C}$ destroyed both the smectites and the kaolinite, leaving the reflections of illite, chlorite, and paragonite visible (Figure $1 \mathrm{~b}$ ). Paragonite is an unusual clay mineral, which is produced by the transport of metamorphic minerals originally from Sierra Nevada [54].

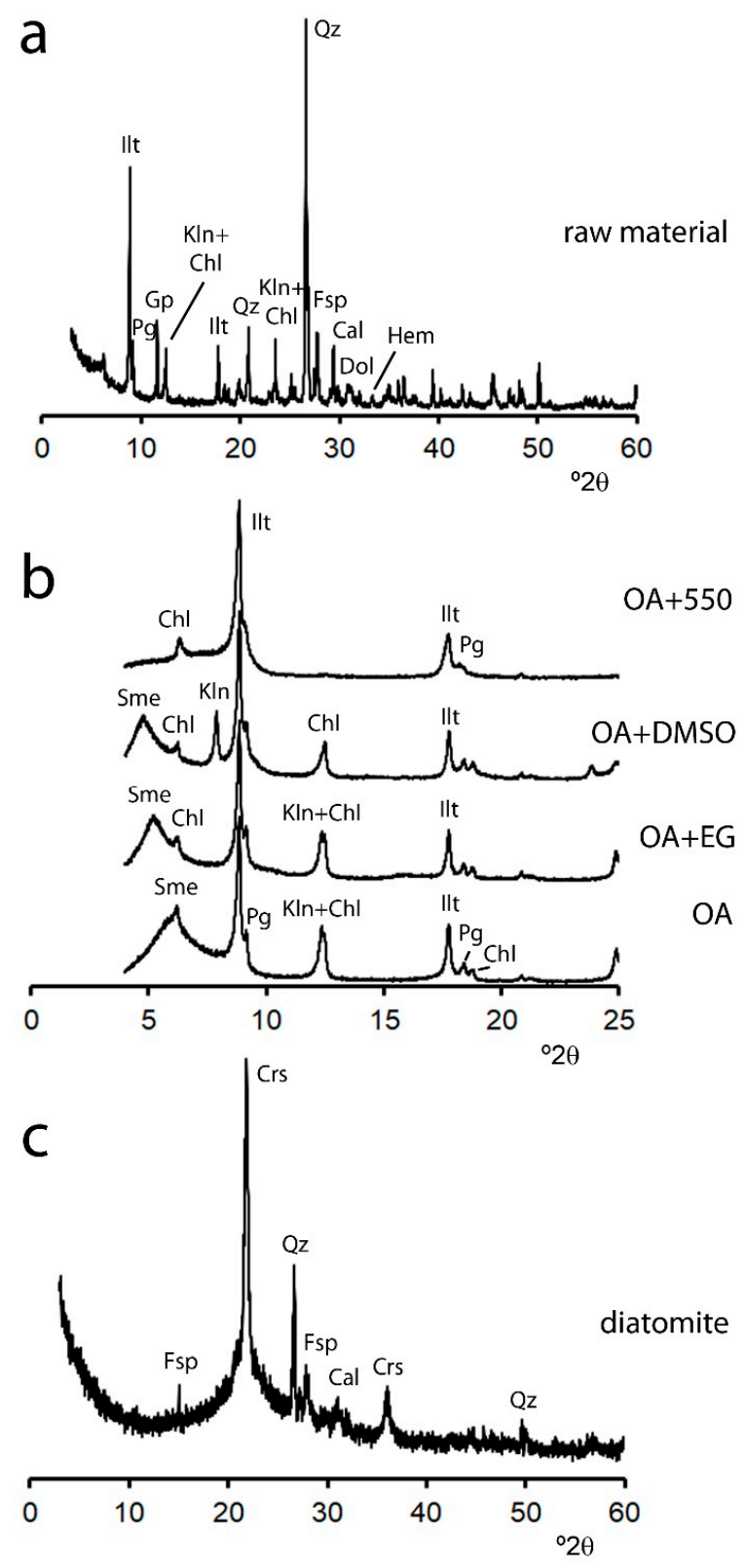

Figure 1. X ray diffraction patterns for the raw material from Jun (a), oriented aggregates from the clay fraction (b) and calcined diatomite sludge (c). Oriented aggregates are: Air-dried (OA), solvated with ethylene-glycol (OA + EG), solvated with dimethyl-sulfoxide (OA + DMSO), heated at $550{ }^{\circ} \mathrm{C}(\mathrm{OA}+550)$. Legend (mineral symbols after Whitney and Evans [55]): Qz = quartz, $\mathrm{Ilt}=$ illite; $\mathrm{Gp}=$ gypsum; Cal = calcite; $\mathrm{Dol}$ = dolomite; Hem = hematite; $\mathrm{Chl}=$ chlorite; $\mathrm{Kln}$ = kaolinite; Fsp = feldspar/plagioclase (in general); Sme = smectite; $\mathrm{Pg}=$ paragonite; $\mathrm{Crs}=$ cristobalite . 
The mineralogy of the diatomite sludge was also studied. It is mainly composed of cristobalite, as well as quartz, calcite, and albite (Figure 1c). In fact, in chemical terms, this sludge was rich in amorphous silica while also having appreciable amounts of calcium (which led to the formation of calcite) and of aluminium and sodium (which enabled the crystallization of albite). As mentioned earlier, sodium carbonate is normally added during the diatomite calcination process as a melting agent. The curve followed by the diffractogram suggests a substantial amount of the amorphous phase.

\subsection{Mineralogy of Fired Bricks}

The mineralogy of the fired samples is similar to that resulting from high temperature metamorphic processes in which the high speed at which the minerals are heated causes extreme reactions, preventing stable phases from developing and favouring the presence of metastable phases [56].

The samples without additives fired at $800{ }^{\circ} \mathrm{C}$ are composed above all of quartz, K-feldspars, and plagioclases (Table 2 and Figure 2). Of the different carbonates identified in the raw material, dolomite is no longer present although there is a small reflection of the calcite at $3.03 \AA$. The types and concentrations of phyllosilicates also diminish, leaving only the dehydroxylated phases of illite and paragonite (Table 2 and Figure 2). At $950{ }^{\circ} \mathrm{C}$, the calcite and paragonite also disappear and the concentrations of illite are reduced. New mineral phases begin to develop at this temperature as a result of the reaction between carbonates and silicates. These include gehlenite and plagioclase, which is now anorthitic due to its enrichment in calcium (Table 2 and Figure 2).

Table 2. Mineralogical composition of the raw material (raw), bricks without additives (J), and with added sodium chloride (JS) and calcined diatomite sludge (JD) fired at $800{ }^{\circ} \mathrm{C}, 950{ }^{\circ} \mathrm{C}$, and $1100{ }^{\circ} \mathrm{C}$. $\mathrm{Qz}=$ quartz (789); Ilt/Ms =illite/muscovite (2013); Chl/Kln = chlorite/ kaolinite (4285); Pg = paragonite (8408); Cal = calcite (98); Dol = dolomite (86); Gp = gypsum (4651); Anh = anhydrite (5117); Hem = hematite (143); $\mathrm{Mc}=$ microcline (5216); Or = orthoclase (313); $\mathrm{Sa}=$ sanidine (18062); $\mathrm{Ab}=$ albite (536); $\mathrm{An}=$ anorthite (370); $\mathrm{Gh}=$ gehlenite (5090); $\mathrm{Di}=$ diopside (1334); Mul = mullite (1059); Crs = cristobalite (10750); Mo = molysite (12857); a / c = amorphous / crystal relationship. AMCSD codes are indicated in brackets after each mineral name. Mineral abbreviations after Whitney and Evans [55].

\begin{tabular}{|c|c|c|c|c|c|c|c|c|c|c|}
\hline Title & Raw & J800 & J950 & J1100 & JS800 & JS950 & JS1100 & JD800 & JD950 & JD1100 \\
\hline Qz & 36.11 & 35.74 & 35.93 & 24.41 & 40.56 & 32.15 & 25.83 & 35.97 & 32.61 & 23.61 \\
\hline $\mathrm{Ilt} / \mathrm{Ms}$ & 9.60 & 9.87 & 7.84 & & 8.36 & 3.22 & & 7.99 & 6.53 & \\
\hline $\mathrm{Chl} / \mathrm{kln}$ & 3.81 & & & & & & & & & \\
\hline Pg & 6.38 & 7.00 & & & 5.95 & & & 5.68 & & \\
\hline Cal & 4.65 & 1.44 & & & & & & 2.36 & & \\
\hline Dol & 1.35 & & & & & & & & & \\
\hline Gp & 6.08 & & & & & & & & & \\
\hline Anh & & 8.99 & 12.99 & 11.01 & 13.08 & 12.88 & & 10.29 & 9.92 & 10.25 \\
\hline Hem & & & 0.81 & 1.55 & 1.55 & 1.33 & 1.23 & 0.74 & 1.37 & 0.87 \\
\hline Mc & 17.90 & 22.97 & & & 17.37 & & & 24.87 & & \\
\hline Or & & & 7.39 & & & 7.79 & & & 9.32 & \\
\hline Sa & & & & 4.23 & & & 11.65 & & & 4.84 \\
\hline $\mathrm{Ab}$ & 14.12 & 13.99 & & & 11.81 & & & 11.38 & & \\
\hline An & & & 29.37 & 49.07 & & 33.48 & 47.51 & & 35.66 & 49.33 \\
\hline Gh & & & 5.67 & 4.40 & & 2.00 & 1.33 & & 3.72 & 3.60 \\
\hline $\mathrm{Di}$ & & & & 5.32 & & 6.20 & 8.56 & & & 6.10 \\
\hline Mul & & & & & & & 3.10 & & & \\
\hline Crs & & & & & & & & 0.72 & 0.88 & 1.40 \\
\hline Mo & & & & & 1.32 & 0.96 & 0.78 & & & \\
\hline$a / c$ & 0.038 & 0.042 & 0.069 & 0.106 & 0.055 & 0.068 & 0.088 & 0.051 & 0.064 & 0.118 \\
\hline
\end{tabular}

The gehlenite may be formed by the following reaction between illite and calcite:

$$
\begin{aligned}
& \text { illite calcite gehlenite } \\
& 2 \mathrm{KAl}_{2}\left(\mathrm{Si}_{3} \mathrm{Al}\right) \mathrm{O}_{10}(\mathrm{OH})_{2}+6 \mathrm{CaCO}_{3} \rightarrow 3 \mathrm{Ca}_{2} \mathrm{Al}_{2} \mathrm{SiO}_{7}+3 \mathrm{SiO}_{2}+\mathrm{K}_{2} \mathrm{O}+2 \mathrm{H}_{2} \mathrm{O}+6 \mathrm{CO}_{2}
\end{aligned}
$$


or by the reaction on the contact edges between potassium feldspar and calcite:

$$
\begin{gathered}
\text { K-feldspar calcite gehlenite } \\
2 \mathrm{KAlSi}_{3} \mathrm{O}_{8}+2 \mathrm{CaCO}_{3} \rightarrow \mathrm{Ca}_{2} \mathrm{Al}_{2} \mathrm{SiO}_{7}+5 \mathrm{SiO}_{2}+\mathrm{K}_{2} \mathrm{O}+2 \mathrm{CO}_{2}
\end{gathered}
$$

Anorthite may appear after the reaction of calcite with quartz and potassium feldspar as follows:

$$
\begin{gathered}
\text { calcite quartz } \mathrm{K} \text {-feldspar anorthite } \\
\mathrm{CaCO}_{3}+2 \mathrm{SiO}_{2}+2 \mathrm{KAlSi}_{3} \mathrm{O}_{8} \rightarrow \mathrm{CaAl}_{2} \mathrm{Si}_{2} \mathrm{O}_{8}+\mathrm{K}_{2} \mathrm{O}+6 \mathrm{SiO}_{2}+\mathrm{CO}_{2}
\end{gathered}
$$

At $1100{ }^{\circ} \mathrm{C}$ there is a considerable increase in anorthite, while the orthoclase is transformed into the most stable high temperature polymorph, sanidine. The diopside formed by the reaction between quartz and dolomite also appears:

$$
\begin{gathered}
\text { dolomite quartz diopside } \\
\mathrm{CaMg}\left(\mathrm{CO}_{3}\right)_{2}+2 \mathrm{SiO}_{2} \rightarrow \mathrm{CaMgSi}_{2} \mathrm{O}_{6}+2 \mathrm{CO}_{2}
\end{gathered}
$$

As the firing temperature increases, hematite starts developing due to the crystallization of the iron present in the raw material.

The concentration of the quartz diminishes above all at $1100^{\circ} \mathrm{C}$ (Table 2) as the edges of the grains of this mineral react with the carbonates to form calcium and magnesium silicates. The fired bricks normally contain anhydrite due to the presence of gypsum in the raw material.

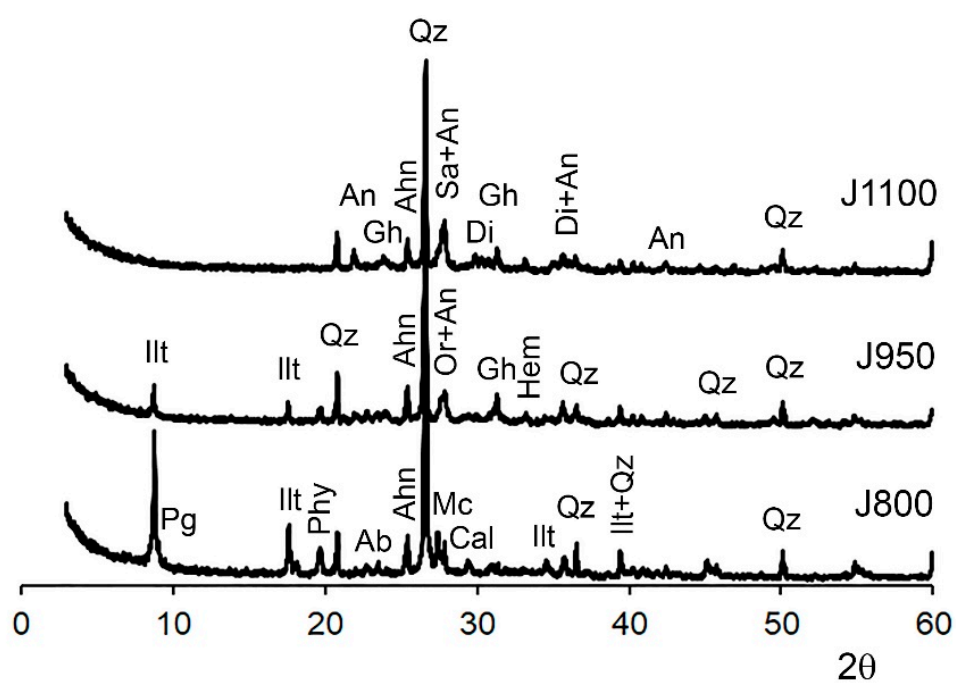

Figure 2. $\mathrm{X}$ ray diffraction patterns of bricks without additives $(\mathrm{J})$ fired at $800{ }^{\circ} \mathrm{C}, 950{ }^{\circ} \mathrm{C}$, and $1100{ }^{\circ} \mathrm{C}$. Legend: $\mathrm{Qz}=$ quartz, Ilt = illite/muscovite; $\mathrm{Pg}=$ paragonite; Phy: phyllosilicates (in general); $\mathrm{Cal}=$ calcite; $\mathrm{Ahn}=$ anhydrite; Hem = hematite; $\mathrm{Mc}=$ microcline; $\mathrm{Or}=$ orthoclase; $\mathrm{Sa}=$ sanidine; $\mathrm{Ab}=$ albite; $\mathrm{An}=$ anorthite; $\mathrm{Gh}=$ gehlenite; $\mathrm{Di}=$ diopside. Minerals abbreviations after Whitney and Evans [55].

The samples that contain sodium chloride and diatomite sludge behave similarly to the samples without additives in the evolution of the mineral phases (Table 2 and Figures 3 and 4). The small differences are manifested in an increase in the concentration of K-feldspar at 950 and $1100{ }^{\circ} \mathrm{C}$. As happens with the samples without additives, an increase in the concentration and the calcium enrichment of plagioclases can be observed as the firing temperature increases. The phyllosilicates undergo a similar process, with a progressive decline in the illite/muscovite, until they disappear completely between 950 and $1100{ }^{\circ} \mathrm{C}$, while paragonite can only be detected in traces up to $800{ }^{\circ} \mathrm{C}$. 
In the presence of sodium chloride, the decline in the amount of quartz begins earlier at $950{ }^{\circ} \mathrm{C}$, when it is consumed in the reaction with the dolomite to form diopside (Table 2).

As the firing temperature increases, there is a constant increase in the proportion of the amorphous phase compared to the crystalline phase in all the samples (with and without additives) (a/c, Table 2). This suggests that the samples are undergoing vitrification. It is important to bear in mind that the a/c ratio in JD samples is due not only to the vitrification of samples, but also to the amorphous phase (organic matter) present in the diatomite sludge (see background noise of XRD pattern in Figure $1 \mathrm{c}$ and LOI value in Table 1). The a/c ratio values indicate that the samples with sodium chloride start vitrifying earlier than the others. Indeed, as $\mathrm{NaCl}$ is a low temperature melting agent, Stimmell et al. [35] observed that it reduced the temperature at which sintering and vitrification of the bricks began at $800{ }^{\circ} \mathrm{C}$. The mineralogy also undergoes more profound changes, bringing forward the appearance of diopside to $950{ }^{\circ} \mathrm{C}$ and increasing its concentration at $1100{ }^{\circ} \mathrm{C}$. Mullite only appears in this group of bricks (Table 2 and Figure 3). On this question, Cultrone et al. [36] observed greater development of newly formed phases in the presence of sodium chloride even when this salt had been added to the bricks in very low concentrations $(0.5 \%)$. Mullite is formed at $1100{ }^{\circ} \mathrm{C}$, replacing the illite/muscovite (epitaxial replacement according to Rodríguez Navarro et al. [57]) in line with the following reaction:

$$
\begin{gathered}
\text { illite } \\
3 \mathrm{KAl}_{2}\left(\mathrm{Si}_{3} \mathrm{Al}\right) \mathrm{O}_{10}(\mathrm{OH})_{2}+2 \mathrm{SiO}_{2} \rightarrow \mathrm{Al}_{6} \mathrm{Si}_{2} \mathrm{O}_{13}+3 \mathrm{KAlSi}_{3} \mathrm{O}_{8}+3 \mathrm{H}_{2} \mathrm{O}
\end{gathered}
$$

Another mineral phase that was identified exclusively in the samples with sodium chloride was molysite $\left(\mathrm{FeCl}_{3}\right)$, a chloride that is rarely found in bricks and is more typical of volcanic fumaroles. This seems to be related with the appearance of unusual yellowy-green halos on the surface of the samples. According to Stimmell et al. [35], who had observed similar marks on bricks made with seawater, the sodium chloride interacts with the clayey matrix, forming $\mathrm{HCl}$. This acid then reacts with the hematite in the matrix, forming iron chloride. These halos are most likely to be found in the places with the highest $\mathrm{Cl}$ concentrations, i.e., where the halite crystals were present.

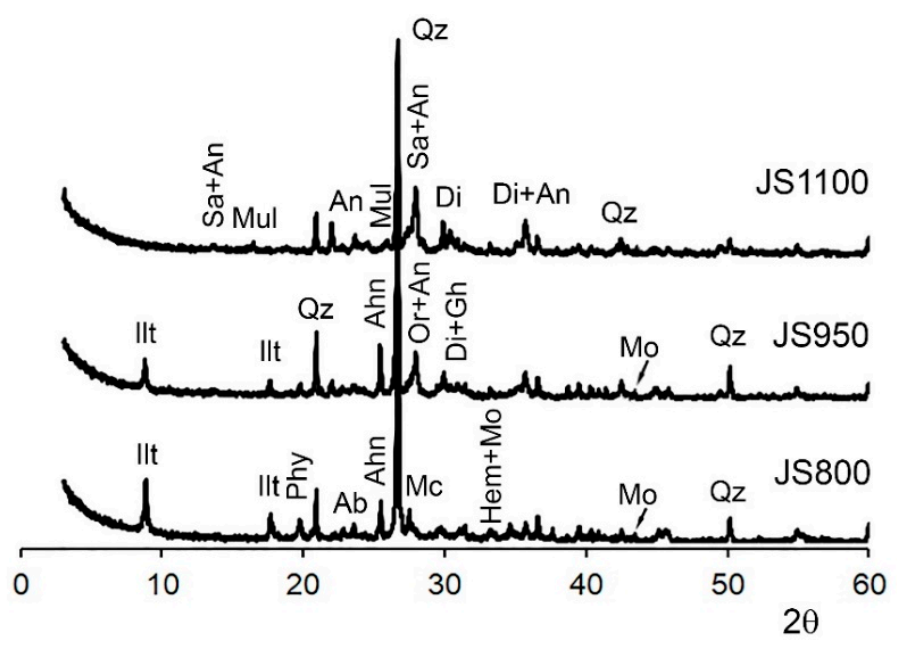

Figure 3. $\mathrm{X}$ ray diffraction patterns of bricks with added sodium chloride (JS) fired at $800{ }^{\circ} \mathrm{C}, 950{ }^{\circ} \mathrm{C}$, and $1100^{\circ} \mathrm{C}$. Legend: $\mathrm{Qz}=$ quartz, Ilt = illite/muscovite; Phy: phyllosilicates (in general); Ahn = anhydrite; $\mathrm{Hem}=$ hematite; $\mathrm{Mc}=$ microcline; $\mathrm{Or}=$ orthoclase; $\mathrm{Sa}=$ sanidine; $\mathrm{Ab}=$ albite; $\mathrm{An}=$ anorthite; $\mathrm{Gh}=$ gehlenite; $\mathrm{Di}=$ diopside; $\mathrm{Mul}=$ mullite; $\mathrm{Mo}=$ molysite. Minerals abbreviations after Whitney and Evans [55]. 
In the samples made with diatomite, traces of cristobalite can be observed at 800 and $950{ }^{\circ} \mathrm{C}$ with higher concentrations at $1100^{\circ} \mathrm{C}$ (Table 2 and Figure 4). The increase in temperature produced the same silicates (gehlenite, anorthite, diopside) observed previously in other bricks.

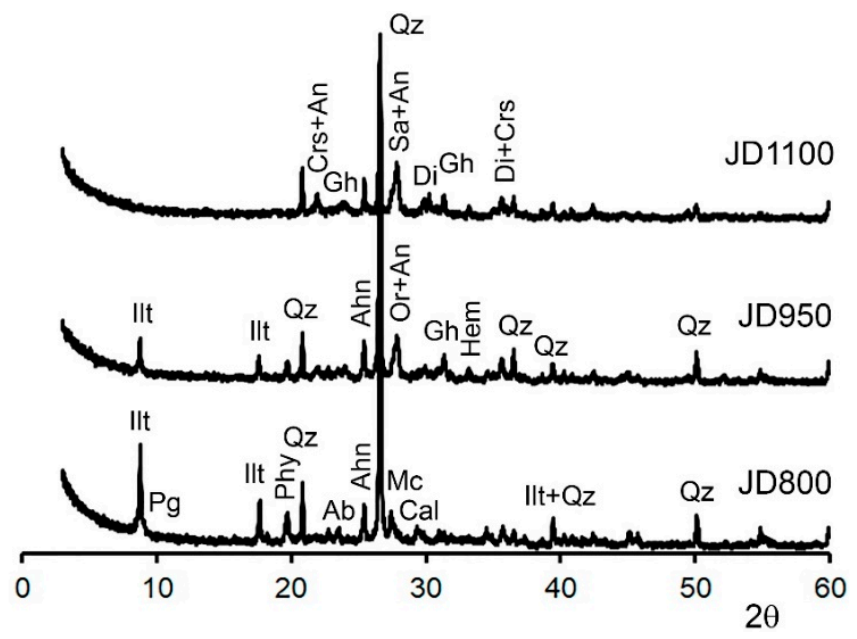

Figure 4. $\mathrm{X}$ ray diffraction patterns of bricks with added calcined diatomite sludge (JD) fired at $800{ }^{\circ} \mathrm{C}$, $950{ }^{\circ} \mathrm{C}$, and $1100{ }^{\circ} \mathrm{C}$. Legend: $\mathrm{Qz}=$ quartz, Ilt = illite/muscovite; $\mathrm{Pg}=$ paragonite; Phy: phyllosilicates (in general); $\mathrm{Cal}=$ calcite; $\mathrm{Ahn}=$ anhydrite; Hem = hematite; $\mathrm{Mc}=$ microcline; $\mathrm{Or}=$ orthoclase; $\mathrm{Sa}=$ sanidine; $\mathrm{Ab}=$ albite; $\mathrm{An}=$ anorthite; $\mathrm{Gh}=$ gehlenite; $\mathrm{Di}=$ diopside; $\mathrm{Crs}=$ cristobalite. Minerals abbreviations after Whitney and Evans [55].

\subsection{Porous System}

The shape of the porometric curves and the height of the main peak are similar to those found in modern brick production [58]. The MIP test showed that the bricks had a unimodal pore size distribution with the maximum peak of pores at around $1 \mu \mathrm{m}$ (Figure 5). This peak shifts towards larger pores as the firing temperature increases, although the said shift is almost imperceptible in the case of bricks without additives, as can be seen in the porometric curves (from $0.4 \mu \mathrm{m}$ at $800{ }^{\circ} \mathrm{C}$ to $0.5 \mu \mathrm{m}$ at 950 and $1100^{\circ} \mathrm{C}$ ). The shift is more pronounced in samples with added $\mathrm{NaCl}$ (from 0.5 $\mu \mathrm{m}$ at $800^{\circ} \mathrm{C}$ to $1 \mu \mathrm{m}$ at $1100{ }^{\circ} \mathrm{C}$ ) and above all, in those with added diatomite sludge (from $0.5 \mu \mathrm{m}$ at $800{ }^{\circ} \mathrm{C}$ to 1.5 at $1100{ }^{\circ} \mathrm{C}$ ). This means that both additives cause alterations in the porous system. The greatest alterations take place with the addition of diatomite sludge, and above all at the highest firing temperature. However, as can be seen in Figure 5, the first six curves (J and JS) are similar, which means that the differences described above are probably not very significant.

While the largest pores generally increase in number from $800^{\circ} \mathrm{C}$ to $1100^{\circ} \mathrm{C}$, the smallest pores fall in number due to the decline in specific surface area (see Table 3 for SSA and pore range of less than $0.1 \mu \mathrm{m}$ ). This happens constantly and in all types of brick. The reduction of SSA is more evident in JS bricks because, as commented earlier, sodium chloride is a low temperature melting agent and causes alterations in the texture of the bricks at $800{ }^{\circ} \mathrm{C}$. In fact, if one compares the results in Table 3 , at $800{ }^{\circ} \mathrm{C}$, the specific surface area of JS bricks is slightly less than $3 \mathrm{~m}^{2} / \mathrm{g}$, while in the other two groups, SSA is well above $5 \mathrm{~m}^{2} / \mathrm{g}$. This indicates that the porous system of the bricks undergoes greater changes in the presence of sodium chloride. These differences are less pronounced at $950{ }^{\circ} \mathrm{C}$ when the other two brick groups also begin to vitrify. However, even at $1100^{\circ} \mathrm{C}$, the JS bricks still show the lowest SSA values (Table 3). These results are important because a lower specific surface area means that the material is less exposed to pollutants and other decay agents [59]. The highest open porosity values were obtained in JD bricks, mainly because of the combustion and subsequent loss of the organic matter present in the diatomite sludge. These bricks reached open porosity values of $45-46 \%$, substantially higher than those for J and JS bricks ( $\mathrm{P}_{\mathrm{oMIP}}$, Table 3 ). Open porosity is a crucial parameter, together with specific surface area and pore size distribution, for assessing the durability of 
porous materials $[58,60]$. There is normally an inverse relation between porosity and durability [61]. These results suggest that the addition of $10 \%$ in weight of diatomite sludge can have negative effects on the durability of bricks. However, in general, all the bricks are very porous because the method of production used in this research (handmade) imitates traditional methods rather than industrial processes (i.e., pressed or extruded) in which porosity values of around $20 \%$ are usual [62]. Real density values ( $\rho_{\text {rMIP }}$, Table 3$)$ were similar in all the samples and were characteristic of the mineralogy of a clayey earth rich in quartz and phyllosilicates. The lowest values were measured in samples with diatomite because of the low density of cristobalite $\left(2.32 \mathrm{~g} / \mathrm{cm}^{3}\right)$, a mineral phase that is only found in JD bricks (Table 2). The lowest apparent density value ( $\rho_{\text {aMIP }}$, Table 3$)$ was again obtained by JD bricks, which is normal since they were the most porous.
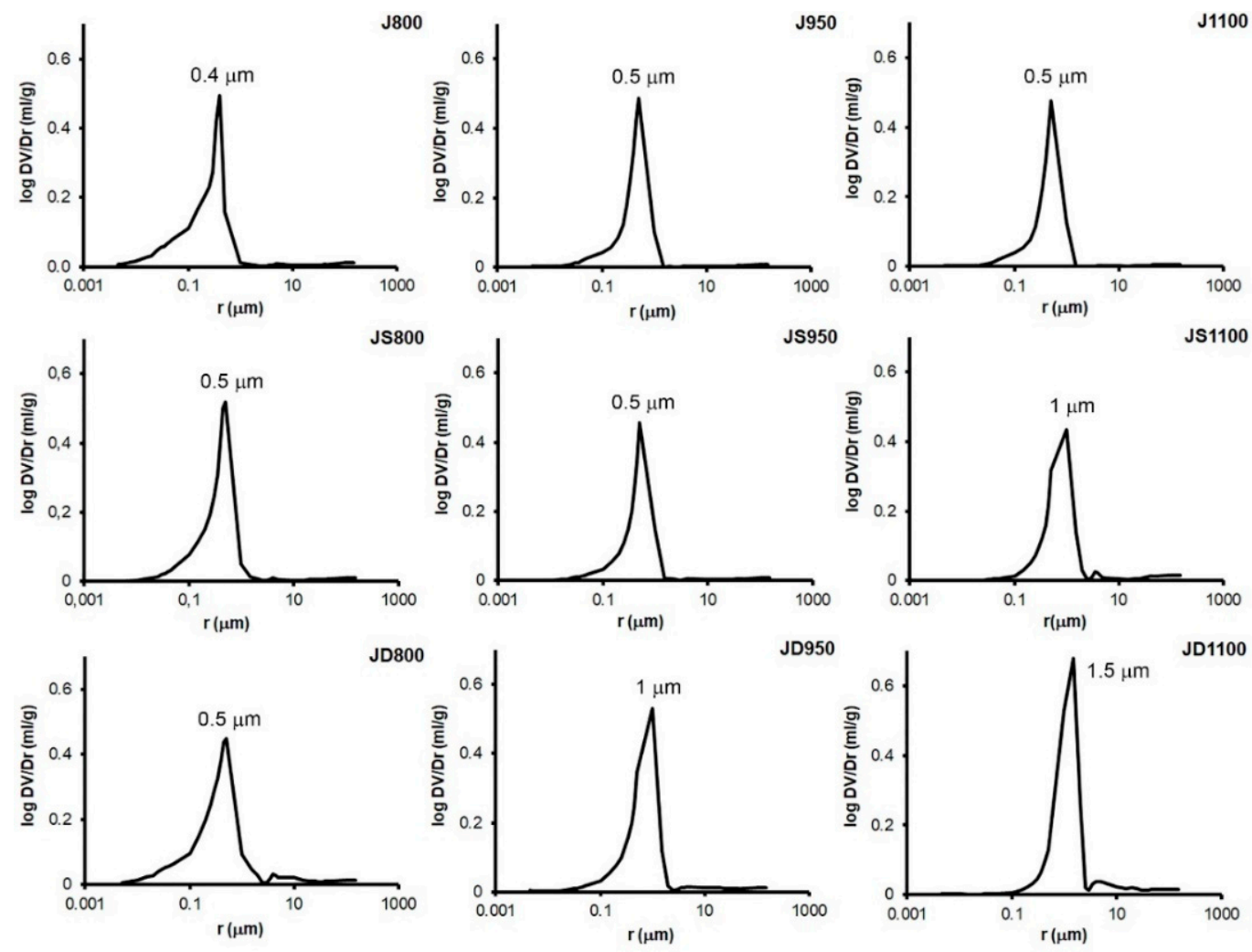

Figure 5. Pore size distribution curves for bricks with and without additives fired at 800, 950, and $1100{ }^{\circ} \mathrm{C}$. Pore radius (in $\mu \mathrm{m}$ ) versus $\log (\mathrm{DV} / \mathrm{Dr})$ (in $\mathrm{mL} / \mathrm{g}$ ). The radius at the maximum peak is indicated.

Table 3. Results of MIP test on brick samples with and without additives fired at 800, 950, and $1100{ }^{\circ} \mathrm{C}$. $\mathrm{SSA}=$ specific surface area $\left(\mathrm{m}^{2} / \mathrm{g}\right) ; \rho_{\mathrm{aMIP}}=$ apparent density $\left(\mathrm{g} \cdot \mathrm{cm}^{-3}\right) ; \rho_{\mathrm{rMIP}}=$ real density $\left(\mathrm{g} \cdot \mathrm{cm}^{-3}\right)$; $\mathrm{P}_{\mathrm{OMIP}}=$ open porosity $(\%)$; relative porosity distribution $(\%)$ according to pore size ranges $(<0.1,0.1-1$, $1-10,>10 \mu \mathrm{m})$.

\begin{tabular}{ccccccccc}
\hline & SSA & $\boldsymbol{\rho}_{\text {aMIP }}$ & $\boldsymbol{\rho}_{\text {rMIP }}$ & $\mathbf{P}_{\text {oMIP }}$ & $<\mathbf{0 . 1}$ & $\mathbf{0 . 1 - 1}$ & $\mathbf{1 - 1 0}$ & $>\mathbf{1 0}$ \\
\hline J800 & 5.85 & 1.49 & 2.41 & 38.32 & 19.41 & 77.02 & 1.50 & 2.07 \\
J950 & 2.27 & 1.47 & 2.44 & 39.75 & 7.19 & 89.47 & 1.10 & 2.24 \\
J1100 & 2.09 & 1.48 & 2.51 & 40.86 & 6.45 & 90.80 & 0.78 & 1.97 \\
JS800 & 2.98 & 1.45 & 2.47 & 41.42 & 8.93 & 86.96 & 2.03 & 2.08 \\
JS950 & 1.77 & 1.46 & 2.51 & 41.75 & 5.80 & 89.68 & 1.93 & 2.59 \\
JS1100 & 1.12 & 1.39 & 2.45 & 43.36 & 2.13 & 78.66 & 13.57 & 5.64 \\
JD800 & 5.48 & 1.29 & 2.41 & 46.43 & 14.65 & 75.54 & 6.32 & 3.49 \\
JD950 & 2.10 & 1.23 & 2.25 & 45.25 & 5.12 & 81.19 & 9.36 & 4.33 \\
JD1100 & 1.32 & 1.28 & 2.31 & 44.83 & 1.45 & 43.41 & 48.40 & 6.75 \\
\hline
\end{tabular}


The hygric tests show how some parameters obtained with this technique are influenced by brick composition, while others depend more on the firing temperature. The water absorption curves, for example, show two clearly defined groups (Figure 6), already identified by MIP: One group contains the bricks made with diatomite sludge (JD) and the other contains the bricks made without additives (J) and with sodium chloride (JS). J and JS absorb a similar amount of water, substantially less than JD. One hour after starting the test, J and JS had reached a 20\% absorption level, while JD was already between $25 \%$ and $30 \%$, depending on the firing temperature of the bricks (Figure 6).

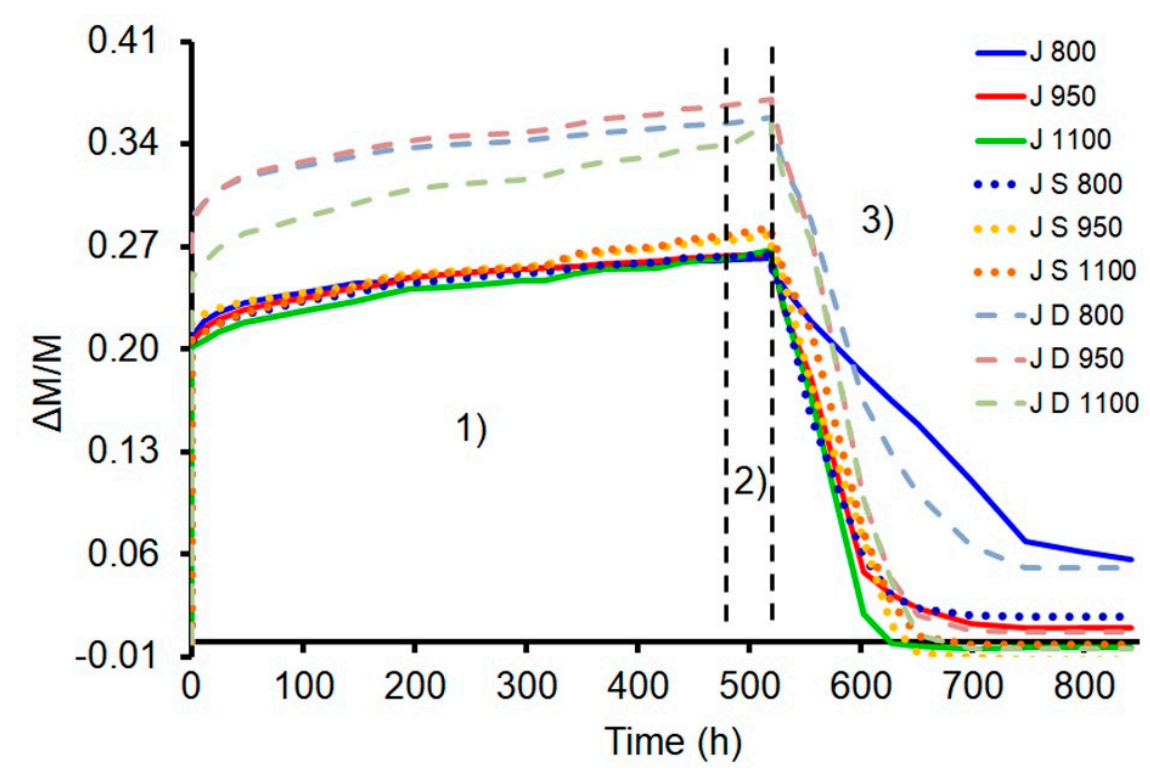

Figure 6. 1) Water absorption at atmospheric pressure, 2) water absorption under vacuum and 3) drying curves for bricks without additives $(\mathrm{J})$, with added sodium chloride $(\mathrm{S})$ and with added calcined diatomite sludge (D) fired at 800,950 , and $1100{ }^{\circ} \mathrm{C}$. Weight variation $(\Delta \mathrm{M} / \mathrm{M})$ versus time (in hours).

At the end of the water absorption test at atmospheric pressure, the group of bricks that had absorbed the least water was J ( $A_{b}$ is around $26 \%$, Figure $7 \mathrm{a}$ ), closely followed by JS ( $A_{b}$ ranges approximately between $26 \%$ and $27.8 \%$ ), while JD showed the highest $A_{b}$ values (between $34 \%$ and $36.7 \%$ ). The differences between the three brick groups observed after the water absorption test at atmospheric pressure remained after the water absorption test under vacuum $\left(A_{f}\right.$, Figure $\left.7 \mathrm{~b}\right)$ and clearly indicate that the addition of diatomite alters the hygric behaviour of bricks. 

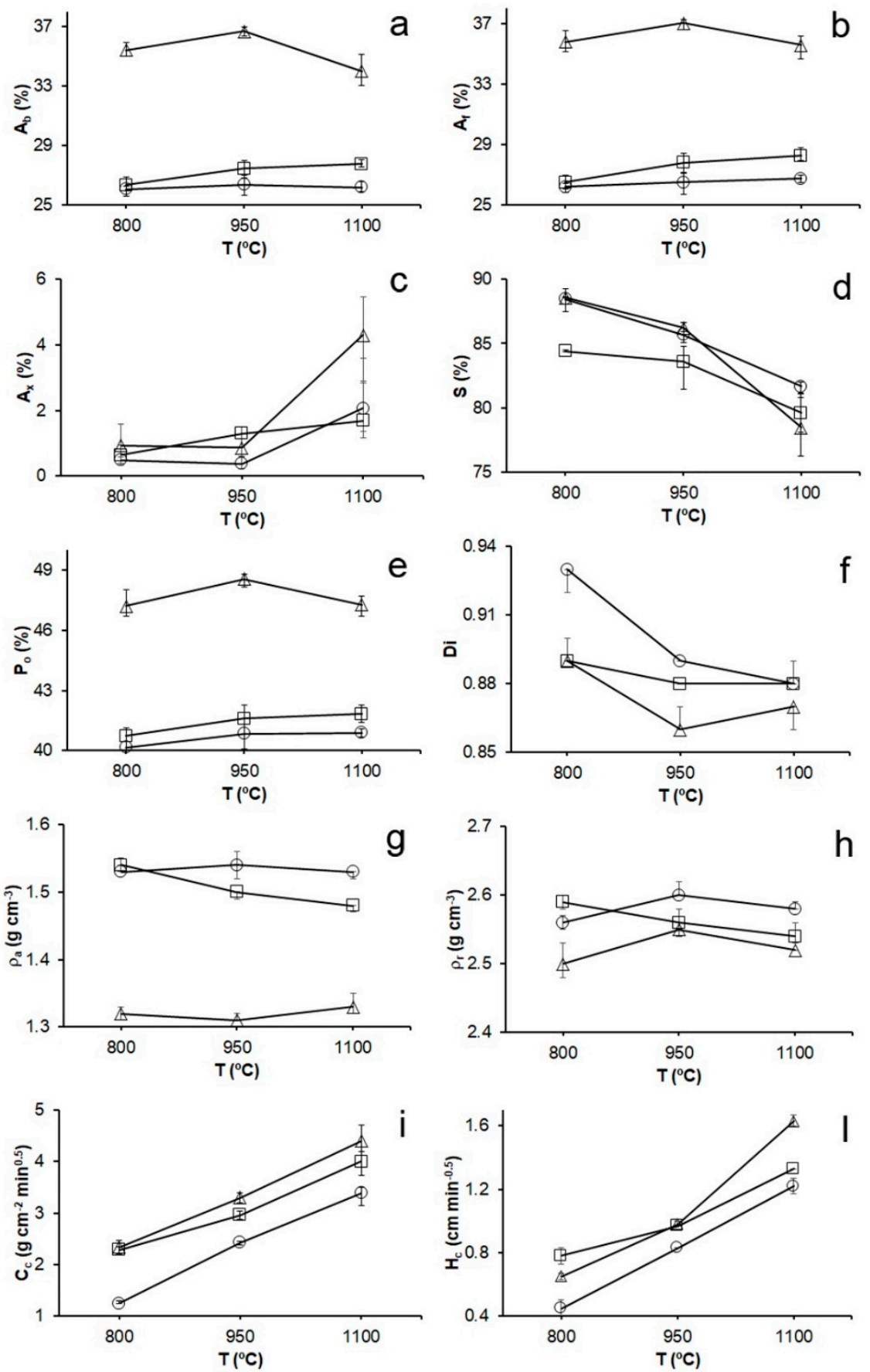

Figure 7. Hygric parameters of brick samples made without additives (open circle), with added sodium chloride (open square) and with added calcined diatomite sludge (open triangle) fired at 800, 950 and $1100{ }^{\circ} \mathrm{C}$. (a) Water absorption at atmospheric pressure $\left(A_{b}\right.$, in \%); (b) water absorption under vacuum $\left(A_{f}\right.$, in \%); (c) saturation coefficient $\left(S\right.$, in \%); (d) degree of pore interconnection $\left(A_{x}\right)$; (e) drying index $(D i)$; (f) open porosity $\left(P_{0}\right.$, in \%); (g) apparent density $\left(\rho_{\mathrm{a}}\right.$, in $\left.\mathrm{g} \mathrm{cm}^{-3}\right)$; $(\mathbf{h})$ real density $\left(\rho_{\mathrm{r}}\right.$, in $\left.\mathrm{g} \cdot \mathrm{cm}^{-3}\right)$; (i) capillarity coefficient $\left(C_{\mathcal{C}}\right.$, in $\left.\mathrm{g} \cdot \mathrm{cm}^{-2} \mathrm{~min}^{0.5}\right)$; (1) capillarity height $\left(H_{\mathcal{C}}\right.$, in $\left.\mathrm{cm} \cdot \mathrm{min}^{-0.5}\right)$. Error bars indicate maximum and minimum values.

The high water absorption capacity of the JD brick group is potentially dangerous for its durability, since the water that flows inside a porous material may contain soluble salts that can crystallize in capillaries, generating fissures or fractures that cause irreparable damage $[63,64]$. The saturation coefficient $(S$, Figure $7 \mathrm{c})$ falls as the firing temperature increases and the degree of interconnection 
between the pores worsens $\left(A_{x}\right.$, Figure $\left.7 \mathrm{~d}\right)$. The latter parameter is related to the tortuous nature of the porous system. As the difference between the values for water absorption at atmospheric pressure $\left(A_{b}\right)$ and water absorption under vacuum $\left(A_{f}\right)$ increases, so $A_{x}$ increases; in other words, it becomes more difficult for water to circulate inside the material [48]. These results indicate that the increase in temperature helps modify the porous system with the development of the vitreous phase and as a result reduces communication between the pores. This hypothesis confirms the MIP data that showed a shift in the maximum pore size peak towards higher sizes and the reduction of specific surface area values (see Figure 5 and Table 3). On this question, Cultrone et al. [9] demonstrated the existence of a direct relationship between the development of vitrification in bricks and the reduction of pore interconnectivity. The XRD results also highlighted an increase in the amount of the amorphous phase in line with the increase in the firing temperature in all the groups of bricks (a/c, Table 2). The drying index $(D i)$ is another key hygric parameter because porous materials are less durable when water is retained inside them over long periods [65]. Di is quite similar in all the samples with only minimal variations according to the firing temperature (Figure 7e). The only exception is J800, which is the slowest sample to dry (see the slope of the drying curve in Figure 6 and the Di value in Figure 7e). Note that J800 is the sample that retained the most water at the end of the drying test followed by JD800 (Figure 6). This is probably because these samples had the largest amounts of small pores of less than $0.1 \mu \mathrm{m}$ (Table 3), the last ones to lose water, which may cause local stresses and cracking [66]. The capillarity test shows an analogous trend to that of water absorption. In fact, the two parameters obtained from this test, the capillary coefficient and the capillary rise height $\left(C_{c}\right.$ and $H_{c}$, respectively, Figure 7i,l), clearly indicate that in all the bricks, water rises more quickly as the firing temperature increases. The open porosity $\left(P_{o}\right.$, Figure $\left.7 \mathrm{f}\right)$ values again show the influence of brick composition in the porous system, especially in the bricks made with diatomite sludge. It is important to remember that this additive has intrinsic porosity that may have increased the capacity of JD bricks to absorb more water and reach higher porosity values than the other bricks. These values are similar to those obtained in the MIP test. The $\rho_{\mathrm{r}}$ value determined by the hygric test is always higher than that calculated using MIP and is closer to the density of the mineral phases identified by XRD (Table 2). In fact, $\rho_{\mathrm{r}}$ ranges between 2.5 and $2.6 \mathrm{~g} / \mathrm{cm}^{3}$, close to the density of quartz $\left(2.66 \mathrm{~g} / \mathrm{cm}^{3}\right)$ and K-feldspar $\left(2.56 \mathrm{~g} / \mathrm{cm}^{3}\right)$. The lowest $\rho_{\mathrm{r}}$ value was again measured in JD samples because of the presence of the low-density mineral, cristobalite, as mentioned earlier in the description of the MIP results. J and JD bricks show a similar trend with lower or values at $800{ }^{\circ} \mathrm{C}$ compared to those at $950{ }^{\circ} \mathrm{C}$ and $1100{ }^{\circ} \mathrm{C}$. This is probably due to the Ca-enrichment of plagioclases ( $\rho_{\mathrm{r}}$ albite is $2.61 \mathrm{~g} / \mathrm{cm}^{3}$, while that of anorthite is $2.76 \mathrm{~g} / \mathrm{cm}^{3}$ ). Instead, JS shows a gradual reduction in $\rho_{\mathrm{r}}$ from $800{ }^{\circ} \mathrm{C}$ to $1100{ }^{\circ} \mathrm{C}$. This can be attributed in part to the reduction in anhydrite $\left(\rho_{\mathrm{r}}\right.$ is $\left.2.95 \mathrm{~g} / \mathrm{cm}^{3}\right)$, which disappears at $1100{ }^{\circ} \mathrm{C}$. Moreover, JS registers a gradual decrease in hematite $\left(5.25 \mathrm{~g} / \mathrm{cm}^{3}\right)$ and molysite $\left(2.91 \mathrm{~g} / \mathrm{cm}^{3}\right)$, while in J and JD, there is an increase in hematite after $800{ }^{\circ} \mathrm{C}$. In general, the small differences observed between the MIP and hygric tests are due to the limitations of each experimental technique, which use different liquids and intrusion pressures. In addition, MIP only considers pores with cylindrical geometry and can erroneously interpret the size of "ink-bottle-shaped" pores [67].

\subsection{Ultrasounds}

In all the samples, the lowest velocity is always $\mathrm{V}_{\mathrm{P} 1}$ due to the position of the phyllosilicates perpendicular to the direction of propagation of the ultrasound waves (Table 4). The phyllosilicates acquired this orientation during the preparation of the test samples due to the pressure exerted when the clayey earth is placed inside the wooden mould. The difference between $V_{P 1}$ and the other two velocities falls as the firing temperature increases, above all at $1100^{\circ} \mathrm{C}$, when the samples are more vitrified and the lamina shape of the crystals is partially lost, so reducing the anisotropy of the pieces $(\Delta M$, Table 4). The comparison of the P-wave velocities in the three orthogonal directions therefore allowed us to verify and confirm the vitrification of bricks in line with the increase in the firing temperature, as had already been deduced by the XRD, MIP, and hygric tests. $V_{P 2}$ and $V_{P 3}$ obtained 
similar values, a fact confirmed by their low relative anisotropy values ( $\Delta m$, Table 4$)$. Exceptions are the samples made with diatomite sludge, which suggests that this additive helps to alter the texture of the bricks (i.e., it modifies the porous system and the orientation of the phyllosilicates). In fact, the total anisotropy of JD samples shows no clear trend, indicating that this additive is randomly oriented inside the bricks and the firing temperature does not help to homogenize the texture ( $\Delta M$, Table 4$)$. For their part, the results for the J and JS groups show that there is an inverse relationship between the anisotropy and the vitrification of the samples, a fact that could be indirectly deduced by the $\mathrm{a} / \mathrm{c}$ ratio (XRD, Table 2). In fact, JS has a lower $\Delta M$ value than J when fired at $800^{\circ} \mathrm{C}$ because of the high vitrification of bricks with added sodium chloride. JS maintains lower anisotropy at $950{ }^{\circ} \mathrm{C}$ (and higher vitrification), but at $1100{ }^{\circ} \mathrm{C}$, the higher a/c value measured in J samples (Table 2) favours a lower degree of anisotropy than JS. The bricks without additives showed the highest velocity values, reaching $2400 \mathrm{~m} / \mathrm{s}$ at $1100{ }^{\circ} \mathrm{C}$, while in the bricks made with added salt or diatomite sludge, the maximum velocity was $2200 \mathrm{~m} / \mathrm{s}$ (Table 4). This velocity is reached in bricks made with salt at $800{ }^{\circ} \mathrm{C}$, another demonstration of the effect of salt as a low-temperature melting agent. When one looks at the mean velocity of $\mathrm{P}$ waves $\left(\overline{V_{p}}\right.$, Table 4$)$, an increase in velocity or, in other words, in compactness can be observed as the firing temperature rises. This increase takes place more gradually when no additives are used. JS and JD follow this trend particularly between 950 and $1100{ }^{\circ} \mathrm{C}$ when the samples are vitrifying (and $\mathrm{NaCl}$ does not have the same influence as at $800^{\circ} \mathrm{C}$ ). The $\mathrm{V}_{\mathrm{P}}$ values are in line with those measured in other bricks fired at similar temperatures [68], mostly when no additives are present. Brick compactness (and mechanical resistance) can therefore vary considerably depending on the type of additive and the percentage added to the clayey material [25]. No comparative data were found in the literature for bricks made with sodium chloride, and although Galán Arboledas et al. [33] had researched the use of diatomite sludge, a comparison with their findings was complicated by the fact that they measured the bending strength instead of the ultrasound velocities and because they followed a different brick manufacturing procedure (extrusion instead of manual).

Table 4. Speed of ultrasonic wave propagation (in $\mathrm{m} / \mathrm{s}$ ), mean velocity $\left(\overline{V_{p}}\right.$, in $\left.\mathrm{m} / \mathrm{s}\right)$, structural $(\Delta M)$, and relative $(\Delta m)$ anisotropies (in \%) of bricks with and without additives fired at 800,950 , and $1100{ }^{\circ} \mathrm{C}$. $V_{P 1}, V_{P 2}$, and $V_{P 3}$ are the ultrasound velocities measured in three orthogonal directions.

\begin{tabular}{ccccccc}
\hline & $\mathbf{V}_{\mathbf{P 1}}$ & $\mathbf{V}_{\mathbf{P 2}}$ & $\mathbf{V}_{\mathbf{P 3}}$ & $\overline{\boldsymbol{V}_{\boldsymbol{p}}}$ & $\boldsymbol{\Delta} \boldsymbol{M}$ & $\boldsymbol{\Delta} \boldsymbol{m}$ \\
\hline J800 & 1625 & 2342 & 2339 & 2102 & 30.56 & 0.12 \\
J950 & 1789 & 2338 & 2337 & 2155 & 23.47 & 0.07 \\
J1100 & 2181 & 2438 & 2392 & 2337 & 9.69 & 1.91 \\
JS800 & 1660 & 2212 & 2234 & 2036 & 25.32 & 0.97 \\
JS950 & 1668 & 1943 & 1967 & 1859 & 14.69 & 1.21 \\
JS1100 & 1804 & 2054 & 2002 & 1953 & 11.02 & 2.58 \\
JD800 & 1610 & 1972 & 2051 & 1877 & 19.96 & 3.91 \\
JD950 & 1514 & 2046 & 1835 & 1798 & 21.99 & 10.85 \\
JD1100 & 1796 & 2102 & 2228 & 2042 & 17.03 & 5.83 \\
\hline
\end{tabular}

\subsection{Colour}

Colour is a very important parameter, given that a change in the colour of the bricks can have a negative effect on the image of the building being constructed or restored. Slight variations in colour are not easily perceived by the human eye, which means that the colour measurement techniques are important for ensuring reliable results for evaluation purposes [69]. There are no important colour differences between the unfired samples without additives and those made with added sodium chloride and only very slight differences with those made with diatomite sludge (Table 5). As the salt is dissolved in the kneading water, it does not alter the colour of the pieces when they dry. The diatomite, however, is added in the form of solid particles in a concentration of $10 \%$ in weight compared to the raw material. The result is that the unfired samples made with this additive are slightly less luminous and have a slightly higher chromaticity. After firing, a reduction in the chromaticity $\left(a^{*}\right.$ and $\left.b^{*}\right)$ and 
lightness $\left(L^{*}\right)$ parameters was observed as the firing temperature increased (Table 5$)$. This means that the bricks become darker and the colour becomes less chromatic ( $C^{*}$ falls). The reddish colour acquired by the bricks is due to the formation of hematite, a phase identified by XRD (Table 2), which, although it is present in low concentrations, is responsible for the red colour of the bricks (Figure 8). The most evident changes took place in the samples made with sodium chloride, which turned lighter (higher $L^{*}$ values and lower $a^{*}$ and $b^{*}$ values compared to the other bricks), with yellow-green halos developing on the surface due to the crystallization of molysite. This fluoride traps the iron in the matrix so preventing the formation of hematite and making the bricks lighter in colour [35]. The halos are of varying size, no larger than $2-3 \mathrm{~mm}$, and have irregularly pigmented the surface of the bricks (Figure 8). The samples fired at $1100{ }^{\circ} \mathrm{C}$ show lower chromaticity values compared to the other bricks and are darker (lower $L^{*}$ value), increasing the contrast with the stains. The difference in colour $(\Delta E$, Table 5) compared to the samples without additives is higher in the bricks with added salt, in which $\Delta E$ values of over 5 were obtained in the samples fired at $950^{\circ} \mathrm{C}$ and $1100{ }^{\circ} \mathrm{C}$, a figure above which the changes in colour start to be appreciable by the human eye [70].

Table 5. Lightness $\left(L^{*}\right)$, chromatic coordinates $\left(a^{*}\right.$ and $\left.b^{*}\right)$, chroma $\left(C^{*}\right)$, hue angle $\left(h\left(^{\circ}\right)\right)$, and colour difference $(\Delta E)$ values for unfired and fired ceramic samples with and without additives.

\begin{tabular}{|c|c|c|c|c|c|c|}
\hline & $L^{*}$ & $a^{*}$ & $b^{*}$ & $C^{*}$ & $h\left(^{\circ}\right)$ & $\Delta E$ \\
\hline $\mathrm{J}$ & $\begin{array}{l}64.10 \\
(0.58)\end{array}$ & $\begin{array}{c}1.11 \\
(0.09)\end{array}$ & $\begin{array}{l}13.76 \\
(0.61)\end{array}$ & $\begin{array}{c}13.80 \\
(0.61)\end{array}$ & $\begin{array}{l}85.40 \\
(0.21)\end{array}$ & - \\
\hline $\mathrm{J} 800$ & $\begin{array}{l}61.87 \\
(0.64)\end{array}$ & $\begin{array}{l}15.08 \\
(0.82)\end{array}$ & $\begin{array}{l}21.22 \\
(0.82)\end{array}$ & $\begin{array}{l}26.03 \\
(1.11)\end{array}$ & $\begin{array}{l}54.61 \\
(0.78)\end{array}$ & - \\
\hline J950 & $\begin{array}{l}62.06 \\
(0.85)\end{array}$ & $\begin{array}{l}16.84 \\
(0.79)\end{array}$ & $\begin{array}{l}21.84 \\
(1.07)\end{array}$ & $\begin{array}{l}27.57 \\
(1.31)\end{array}$ & $\begin{array}{l}52.37 \\
(0.54)\end{array}$ & - \\
\hline J1100 & $\begin{array}{l}61.24 \\
(3.17)\end{array}$ & $\begin{array}{l}11.01 \\
(1.38)\end{array}$ & $\begin{array}{l}19.67 \\
(0.74)\end{array}$ & $\begin{array}{l}22.57 \\
(0.88)\end{array}$ & $\begin{array}{c}60.82 \\
(3.29)\end{array}$ & - \\
\hline JS & $\begin{array}{l}63.63 \\
(2.43)\end{array}$ & $\begin{array}{c}1.22 \\
(0.20)\end{array}$ & $\begin{array}{l}14.24 \\
(0.45)\end{array}$ & $\begin{array}{l}14.30 \\
(0.47)\end{array}$ & $\begin{array}{l}85.13 \\
(0.66)\end{array}$ & 0.94 \\
\hline JS800 & $\begin{array}{l}66.98 \\
(1.38)\end{array}$ & $\begin{array}{l}11.19 \\
(1.48)\end{array}$ & $\begin{array}{l}18.50 \\
(0.85)\end{array}$ & $\begin{array}{l}21.64 \\
(1.32)\end{array}$ & $\begin{array}{l}58.94 \\
(2.87)\end{array}$ & 3.33 \\
\hline JS950 & $\begin{array}{l}65.60 \\
(0.74)\end{array}$ & $\begin{array}{l}11.04 \\
(1.82)\end{array}$ & $\begin{array}{c}19.37 \\
(1.71)\end{array}$ & $\begin{array}{l}22.31 \\
(2.33)\end{array}$ & $\begin{array}{l}60.46 \\
(2.24)\end{array}$ & 5.91 \\
\hline JS1100 & $\begin{array}{l}62.47 \\
(8.92)\end{array}$ & $\begin{array}{c}7.48 \\
(1.90)\end{array}$ & $\begin{array}{l}18.38 \\
(1.55)\end{array}$ & $\begin{array}{l}19.92 \\
(1.52)\end{array}$ & $\begin{array}{l}67.85 \\
(5.41)\end{array}$ & 5.15 \\
\hline JD & $\begin{array}{l}61.97 \\
(1.02)\end{array}$ & $\begin{array}{c}2.00 \\
(0.21)\end{array}$ & $\begin{array}{l}16.33 \\
(0.70)\end{array}$ & $\begin{array}{l}16.46 \\
(0.72)\end{array}$ & $\begin{array}{l}83.04 \\
(0.43)\end{array}$ & 3.14 \\
\hline JD800 & $\begin{array}{c}62.51 \\
(1.00)\end{array}$ & $\begin{array}{l}15.30 \\
(0.75)\end{array}$ & $\begin{array}{l}21.32 \\
(0.66)\end{array}$ & $\begin{array}{l}26.24 \\
(0.97)\end{array}$ & $\begin{array}{l}54.34 \\
(0.61)\end{array}$ & 2.66 \\
\hline JD950 & $\begin{array}{l}63.53 \\
(3.70)\end{array}$ & $\begin{array}{l}17.13 \\
(2.96)\end{array}$ & $\begin{array}{l}22.47 \\
(2.94)\end{array}$ & $\begin{array}{l}28.25 \\
(4.12)\end{array}$ & $\begin{array}{l}52.83 \\
(1.34)\end{array}$ & 4.20 \\
\hline JD1100 & $\begin{array}{l}57.20 \\
(1.82)\end{array}$ & $\begin{array}{l}11.95 \\
(2.44)\end{array}$ & $\begin{array}{l}20.93 \\
(0.94)\end{array}$ & $\begin{array}{l}24.15 \\
(1.97)\end{array}$ & $\begin{array}{l}60.54 \\
(4.09)\end{array}$ & 3.69 \\
\hline
\end{tabular}




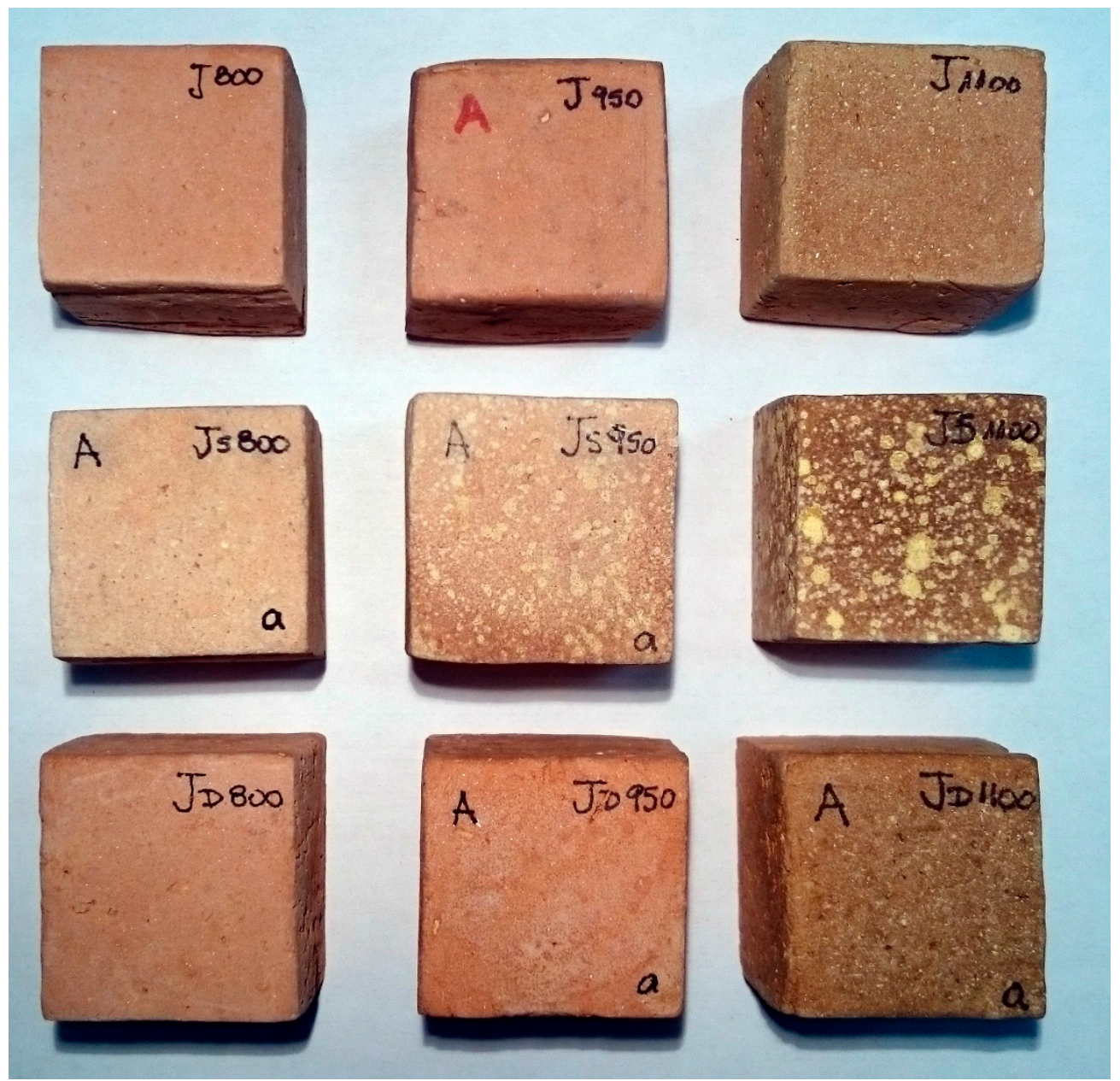

Figure 8. Appearance of fired bricks without additives (J) and with added sodium chloride (JS) and calcined diatomite sludge (JD) fired at 800,950 , and $1100^{\circ} \mathrm{C}$. Brick cubes have a $4 \mathrm{~cm}$-edge.

\section{Conclusions}

In this paper, bricks made with a raw material from Jun (Granada, Spain) and fired at $800{ }^{\circ} \mathrm{C}$, $950{ }^{\circ} \mathrm{C}$, and $1100^{\circ} \mathrm{C}$ were characterized in mineralogical and physical terms and compared to others to which sodium chloride and calcined diatomite sludge were added, so as to find out whether these additives improved the engineering properties of the bricks. The raw material underwent mineralogical changes during the brick firing process. This was due to the decomposition of the carbonates and phyllosilicates and their interaction with quartz and feldspars to form new silicates (gehlenite, anorthite, and diopside). The inclusion of additives led to further mineralogical changes, such as the appearance of molysite and mullite when sodium chloride was added, and of cristobalite when calcined diatomite sludge was used.

All the brick samples vitrified as the firing temperature increased (the amount of amorphous phase increased compared to the crystalline matter). This gave rise to changes in the porous system, such as an increase in the size of the pores, at the same time as reducing the degree of interconnection between them. This is presumably due to the development of a "cellular structure" [71] in which the pores coalesce, increasing in size due to the fusion of the clayey particles. The use of diatomite sludge gave rise to bricks, which were more porous and had a higher water absorption capacity than the other brick groups studied in this paper. This was also due to the diatom particles, which have intrinsic porosity.

Greater vitrification also led to an increase in the compactness of the bricks and was more accentuated when no additives were used. It must be emphasized that the bricks with added 
sodium chloride were already highly compact at $800{ }^{\circ} \mathrm{C}$, as salt allows melting to take place at lower temperatures. In fact, these were the bricks with the largest amounts of the amorphous phase at this temperature.

In terms of their aesthetic appearance, the bricks got gradually darker as the firing temperature increased, above all at $1100{ }^{\circ} \mathrm{C}$ and even more so when the diatomite sludge was added. The addition of sodium chloride produced yellower bricks because part of the iron responsible for the red pigmentation of the bricks is consumed in the formation of molysite and cannot crystallize as hematite. The yellow colour was not uniformly distributed on the surface of the bricks and appeared in the form of spots or stains. These stains may indicate a higher concentration of molysite crystals where the presence of halite was highest.

At a general level, the best physical characteristics were found in the samples fired at the highest temperature. However, if bricks can be fired at lower temperatures, this reduces production costs considerably as less energy is consumed. In this case, the bricks made with added sodium chloride fired at $800^{\circ} \mathrm{C}$ could be a valid alternative to those made without additives and fired at 950 and $1100{ }^{\circ} \mathrm{C}$. This is because partially vitrified and, therefore, more compact bricks can be obtained at $800^{\circ} \mathrm{C}$ thanks to the fact that salt acts as a melting agent. Moreover, at $800{ }^{\circ} \mathrm{C}$, the stains on the surface of the bricks are practically invisible compared to those fired at 950 and $1100{ }^{\circ} \mathrm{C}$, which makes them aesthetically acceptable in situations in which a uniform appearance is required. There is some potential in the use of diatomite in brick-making, as bricks made with this additive have a similar degree of compactness to other bricks. The most obvious difference is their higher porosity. Its possible use as an additive in bricks for thermal insulation should be investigated. The durability of these bricks could be analysed in future research in order to obtain a more complete picture of their technical quality. This study has provided new data on the mineralogical and physical changes that take place in bricks due to the addition of sodium chloride and calcined diatomite sludge. These data will be useful for the brick industry both in new constructions and in the conservation of historic buildings.

Author Contributions: M.L.E. performed the experiments and revised the manuscript; G.C. conceived the research, wrote and revised the manuscript.

Funding: This study was funded by Junta de Andalucía Research Group RNM179, by Research Project MAT2016-75889-R and by the Eureka SD project (agreement number 2013-2591), which is supported by the Erasmus Mundus programme of the European Union.

Acknowledgments: We thank Cerámica Castillo Siles for providing the raw material used to prepare and fire the bricks and Cervezas Alhambra S.L. (Granada) for providing the calcined diatomite sludge. We are grateful to Nigel Walkington for his assistance in translating the original text.

Conflicts of Interest: The authors declare no conflict of interest. The funders had no role in the design of the study; in the collection, analyses, or interpretation of data; in the writing of the manuscript, or in the decision to publish the results.

\section{References}

1. Warren, J. Conservation of Bricks; Butterworth Heinemann: Oxford, UK, 1999.

2. Hansen, W.; Kung, J.H. Pore structure and frost durability of clay bricks. Mater. Struct. 1988, 21, $443-447$. [CrossRef]

3. Robinson, G.C. The relationship between pore structure and durability of bricks. Ceram. Bull. 1984, 63, 295-300.

4. Winslow, D.N.; Kilgour, C.L.; Crooks, R.W. Predicting the durability of bricks. J. Test. Eval. 1988, 16, 527-531.

5. Lu, G.; Lu, G.Q.; Xiao, Z.M. Mechanical properties of porous materials. J. Porous Mat. 1999, 6, $359-368$. [CrossRef]

6. Elert, K.; Cultrone, G.; Rodriguez Navarro, C.; Sebastian Pardo, E. Durability of bricks used in the conservation of historic buildings. Influence of composition and microstructure. J. Cult. Herit. 2003, 4, 91-99. [CrossRef]

7. Djuric, M.; Marinkovic Neducin, R.; Ranogajec, J.; Radeka, M. Particle size range as a factor influencing compressibility of ceramic powder. Ceram. Int. 1995, 21, 227-230. [CrossRef] 
8. Sveda, M. New look at mathematical relationship among physical properties of brick products. Br. Ceram. Trans. 2000, 99, 181-186. [CrossRef]

9. Cultrone, G.; Sebastián, E.; Elert, K.; de la Torre, M.J.; Cazalla, O.; Rodriguez Navarro, C. Influence of mineralogy and firing temperature on the porosity of bricks. J. Eur. Ceram. Soc. 2004, 24, 547-564. [CrossRef]

10. Freyburg, S.; Schwarz, A. Influence of the clay type on the pore structure of structural ceramics. J. Eur. Ceram. Soc. 2007, 27, 1727-1733. [CrossRef]

11. De Bonis, A.; Cultrone, G.; Grifa, C.; Langella, A.; Leone, A.P.; Mercurio, M.; Morra, V. Different shades of red: The complexity of mineralogical and physic-chemical factors influencing the colour of ceramics. Ceram. Int. 2017, 43, 8065-8074. [CrossRef]

12. Cerdeño del Castillo, J.; Díaz Rubio, R.; Obis Sánchez, J.; Pérez Lorenzo, A.; Velasco Vélez, J. Manual de Patologías de las Piezas Cerámicas para la Construcción; AITEMIN: Toledo, Spain, 2000.

13. Coletti, C.; Cultrone, G.; Maritan, L.; Mazzoli, C. How to face the new industrial challenge of compatible, sustainable brick production: Study of various types of commercially available bricks. Appl. Clay Sci. 2016, 124-125, 219-226. [CrossRef]

14. Manning, D.A.C. Introduction to Industrial Minerals; Chapman \& Hall: London, UK, 1995.

15. Parras, J.; Sánchez Jiménez, C.; Rodas, M.; Luque, F.J. Ceramic applications of Middle Ordovician shales from central Spain. Appl. Clay Sci. 1996, 11, 25-41. [CrossRef]

16. González, I.; Galán, E.; Miras, A.; Aparicio, P. New uses for brick-making clay materials from the Bailén area (Southern Spain). Clay Miner. 1998, 33, 453-465. [CrossRef]

17. Dondi, M.; Ercolani, B.; Fabbri, B.; Guarini, G.; Marsigli, M.; Mingazzini, C. Major deposits of brick clays in Italy. Part 2: Technological properties and uses. Tile Brick Int. 1999, 15, 360-370.

18. Woolley, G.R.; Wainwright, P.J.; Goumans, J.J.J.M. Science and engineering of recycling for environmental protection: An overview of the WASCON 2000 Conference. Waste Manag. 2001, 21, 211-212. [CrossRef]

19. Goel, G.; Kalamdhad, A.S.; Agrawal, A. Parameter optimisation for producing fired bricks using organic solid wastes. J. Clean. Prod. 2018, 205, 836-844. [CrossRef]

20. Bianchini, G.; Marrocchino, E.; Tassinari, R.; Vaccaro, C. Recycling of construction and demolition waste materials: A chemical-mineralogical appraisal. Waste Manag. 2005, 25, 149-159. [CrossRef] [PubMed]

21. Bories, C.; Borredon, M.E.; Vedrenne, E.; Vilarem, G. Development of eco-friendly porous fired clay bricks using pore-forming agents: A review. J. Environ. Manag. 2014, 143, 186-196. [CrossRef]

22. Singer, F.P.; Singer, S.S. Cerámica Industrial. Vol. I: Principios Generales de la Fabricación Cerámica; URMO, S.A. de Ediciones: Bilbao, Spain, 1979.

23. Kadir, A.A.; Mohajerani, A. Bricks: An excellent building material for recycling wastes. A review. In Proceedings of the IASTED International Conference Environmental Management and Engineering (EME 2011), Calgary, AB, Canada, 4-6 July 2011; pp. 108-115.

24. Monteiro, S.N.; Fontes Vieira, C.M. On the production of fired clay bricks from waste materials: A critical update. Constr. Build. Mater. 2014, 68, 599-610. [CrossRef]

25. Muñoz Velasco, P.; Morales Ortíz, M.P.; Mendívil Giró, M.A.; Muñoz Velasco, L. Fired clay bricks manufactured by adding wastes as sustainable construction material. A review. Constr. Build. Mater. 2014, 63, 97-107. [CrossRef]

26. Zhang, Z.; Wong, Y.C.; Arulrajah, A.; Horpibulsuk, S. A review of studies on bricks using alternative materials and approaches. Constr. Build. Mater. 2018, 188, 1101-1118. [CrossRef]

27. Coletti, C. BRICKTECH: Assessment for the Use of Waste in Brick Production. Petrophysical Characterization of New Mix Designs and Optimization of the Firing Conditions. Ph.D. Thesis, University of Padova, Padova, Italy, University of Granada, Granada, Spain, 2016.

28. Ediz, N.; Bentli, I.; Tatar, I. Improvement in filtration characteristics of diatomite by calcination. Int. J. Miner. Process. 2010, 94, 129-134. [CrossRef]

29. Hadjar, H.; Hamdi, B.; Jaber, M.; Brendlé, J.; Kessaïssia, Z.; Balard, H.; Donnet, J.B. Elaboration and characterisation of new mesoporous materials from diatomite and charcoal. Microporous Mesoporous Mater. 2008, 107, 219-226. [CrossRef]

30. Breese, R.O.I. Diatomite. In Industrial Minerals and Rocks, 6th ed.; Carr, D.D., Ed.; Society for Mining and Metallurgy and Exploration Inc.: Littleton, CO, USA, 1994; pp. 397-412.

31. Zhang, X.; Liu, X.; Meng, G. Sintering kinetics of porous ceramics from natural diatomite. J. Am. Ceram. Soc. 2005, 88, 1826-1830. [CrossRef] 
32. Lin, K.L.; Chang, J.C. Feasibility of recycling waste diatomite and fly ash cosintered as porous ceramics. Environ. Prog. Sustain. Energy 2013, 32, 25-34. [CrossRef]

33. Galán Arboledas, R.J.; Cotes Palomino, M.T.; Bueno, S.; Martínez García, C. Evaluation of spent diatomite incorporation in clay based materials for lightweight bricks processing. Constr. Build. Mater. 2017, 144, 327-337. [CrossRef]

34. Rye, O.S. Keeping your temper under control: Materials and manufacture of Papuan pottery. Archeol. Phys. Anthropol. Ocean. 1976, 11, 106-137.

35. Stimmell, C.; Heimann, R.B.; Hancock, R.G.V. Indian pottery from Mississippi valley: Copying with bad raw materials. In Archaeological Ceramics; Smithsonian Institution Press: Washington, DC, USA, 1982; pp. 219-228.

36. Cultrone, G.; Sebastián, E.; de la Torre, M.J. Mineralogical and physical behaviour of solid bricks with additives. Constr. Build. Mater. 2005, 19, 39-48. [CrossRef]

37. Laird, R.T.; Worcerster, M. The inhibiting of lime blowing. Trans. Br. Ceram. Soc. 1956, 55, 545-563.

38. Govindaraju, K. Compilation of working values and sample description for 383 geostandards. Geostandard. Newsl. 1994, 18, 1-158. [CrossRef]

39. De Jongh, W.K. X-ray fluorescence analysis applying theoretical matrix corrections. Stainless steel. X-Ray Spectrom. 1973, 2, 151-158. [CrossRef]

40. Martin, J.D. XPowder, XPowder12, XPowderXTM; A Software Package for Powder X-ray Diffraction Analysis. Available online: http:/ / www.xpowder.com/download/xpowder.pdf (accessed on 18 January 2018).

41. Bruton, G. Vapour glycolation. Am. Mineral. 1955, 40, 124-126.

42. González García, F.; Sánchez Camazano, M. Differentiation of kaolinite from chlorite by treatment with dimetylsulfoxide. Clay Miner. 1968, 7, 447-450. [CrossRef]

43. Charola, A.E.; Wendler, E. An overview of the water-porous building materials interactions. Restor. Build. Monum. 2015, 21, 55-65. [CrossRef]

44. UNE-EN 13755. Natural Stone Test Methods. Determination of Water Absorption at Atmospheric Pressure; AENOR: Madrid, Spain, 2008.

45. Esbert, R.M.; Ordaz, J.; Alonso, F.J.; Montoto, M. Manual de Diagnosis y Tratamiento de Materiales Pétreos y Cerámicos; Col.legi d'Aparelladors i Arquitects Tècnics de Barcelona: Barcelona, Spain, 1997.

46. Normal 29/88. Misura Dell'indice di Asciugamento (Drying Index); CNR-ICR: Rome, Italy, 1988.

47. UNE-EN 1925. Natural Stone Test Methods. Determination of Water Absorption Coefficient by Capillarity; AENOR: Madrid, Spain, 1999.

48. Cultrone, G.; de la Torre, M.J.; Sebastián, E.; Cazalla, O. Evaluation of bricks durability using destructive and non-destructive methods (DT and NDT). Mater. Constr. 2003, 53, 41-59. [CrossRef]

49. RILEM. Recommended test to measure the deterioration of stone and to assess the differences of treatment methods. Mater. Struct. 1980, 13, 175-253.

50. ASTM D2845. Standard Test Method for Laboratory Determination of Pulse Velocities and Ultrasonic Elastic Constant of Rock; ASTM: West Conshohocken, PA, USA, 2005.

51. Guydader, J.; Denis, A. Propagation des ondes dans les roches anisotropies sous contrainte évaluation de la qualité des schistes ardoisers. Bull. Eng. Geol. 1986, 33, 49-55. [CrossRef]

52. Conservation of Cultural Property. Test Methods. Colour Measurement of Surfaces; I.S. EN 15886:2010; AENOR: Madrid, Spain, 2011.

53. López Quirós, A.; Barbier, M.; Martín, J.M.; Puga Bernabéu, A.; Guichet, X. Diagenetic evolution of Tortonian temperate carbonates close to evaporites in the Granada Basin (SE Spain). Sediment. Geol. 2016, 335, 180-196. [CrossRef]

54. Martin, J.M.; Ortega Huertas, M.; Torres Ruiz, J. Genesis and evolution of strontium deposits of the Granada basin (Southeastern Spain): Evidence of diagenetic replacement of a stromatolite belt. Sediment. Geol. 1984, 39, 28-298. [CrossRef]

55. Whitney, D.L.; Evans, B.W. Abbreviations for names of rock-forming minerals. Am. Mineral. 2010, 95, 185-187. [CrossRef]

56. Grapes, R. Pyrometamorphism; Springer: Berlin, Germany, 2010.

57. Rodriguez Navarro, C.; Cultrone, G.; Sánchez Navas, A.; Sebastián, E. TEM study of mullite growth after muscovite breakdown. Am. Mineral. 2003, 88, 713-724. [CrossRef]

58. Benavente, D.; García del Cura, M.A.; Fort, R.; Ordóñez, S. Durability estimation of porous building stones from pore structures and strength. Eng. Geol. 2004, 74, 113-127. [CrossRef] 
59. Whiteley, P.; Russman, H.D.; Bishop, J.D. Porosity of building materials. A collection of published results. J. Oil Colour Chem. Assoc. 1977, 60, 142-150.

60. Coletti, C.; Cultrone, G.; Maritan, L.; Mazzoli, C. Combined multi-analytical approach for study of pore system in bricks: How much porosity is there? Mater. Charact. 2016, 121, 82-92. [CrossRef]

61. Molina, E.; Cultrone, G.; Sebastián, E.; Alonso, F.J.; Carrizo, L.; Gisbert, J.; Buj, O. The pore system of sedimentary rocks as a key factor in the durability of building materials. Eng. Geol. 2011, 118, 110-121. [CrossRef]

62. Krakowiak, K.J.; Lourenço, P.B.; Ulm, F.J. Multitechnique investigation of extruded clay brick microstructure. J. Am. Ceram. Soc. 2011, 94, 3012-3022. [CrossRef]

63. Scherer, G.W. Crystallization in pores. Cem. Concr. Res. 1999, 29, 1347-1358. [CrossRef]

64. Dohene, E.; Price, C.A. Stone Conservation. An Overview of Current Research; The Getty Conservation Institute: Los Angeles, CA, USA, 2010.

65. Karagiannis, N.; Karoglou, M.; Bakolas, A.; Krokida, M.; Moropoulou, A. Drying kinetics of building materials capillary moisture. Constr. Build. Mater. 2017, 137, 441-449. [CrossRef]

66. Scherer, G.W. Theory of drying. J. Am. Ceram. Soc. 1990, 73, 3-14. [CrossRef]

67. Del Rey Bueno, F. Porosimetría de mercurio. In Técnicas de Diagnóstico Aplicadas a la Conservación de los Materiales de Construcción en los Edificios Históricos; Cuadernos Técnicos vol. 2; Junta de Andalucía: Seville, Spain, 1996; pp. 46-65.

68. Cultrone, G.; Sebastián, E.; Cazalla, O.; Nechar, M.; Romero, R.; Bagur, M.G. Ultrasound and mechanical tests combined with ANOVA to evaluate brick quality. Ceram. Int. 2001, 27, 401-406. [CrossRef]

69. Brimblecombe, P.; Grossi, C.M. Aesthetic threshold and blackening of stone buildings. Sci. Total Environ. 2005, 349, 175-189. [CrossRef] [PubMed]

70. Grossi, C.M.; Brimblecombe, P.; Esbert, R.M.; Alonso, F.J. Colour changes in architectural limestones from pollution and cleaning. Colour Res. Appl. 2007, 32, 320-331. [CrossRef]

71. Tite, M.S.; Maniatis, Y. Examination of ancient pottery using the scanning electron microscope. Nature 1975, 257, 122-123. [CrossRef] 